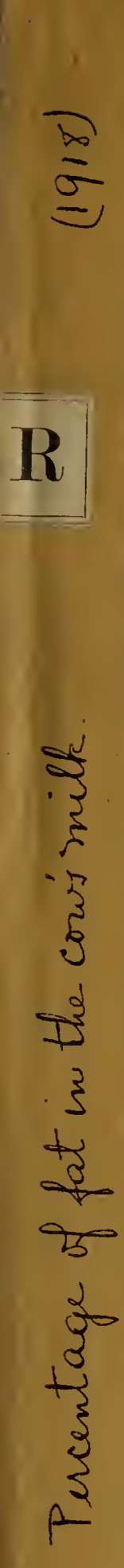


HARVARD UNIVERSITY.

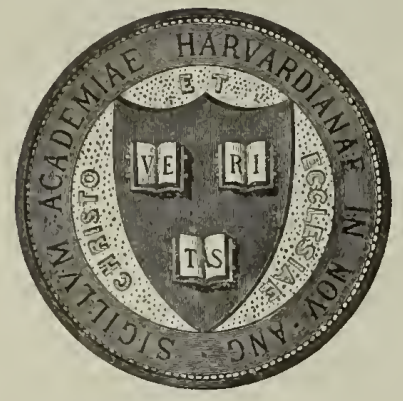

LIBRARY

OF THE

MUSEUM OF COMPARATIVE ZOÖLOGY 66.272

GIFT OF

$$
\text { Wilkam in. Wheeler }
$$

Apuil 2.1926 


\section{6,272 AnI 21980}

CORRELATION BETWEEN THE PERCENTAGE OF FAT IN COW'S MILK AND THE YIELD

ELMER ROBERTS

Reprinted from JOURNAL OF AGRICULTURAL RESEARCH

Vol. XIV, No. $2 \quad$ : : : : : Washington, D. C., July 8, 1918

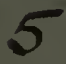

PUBLISHED BY AUTHORITY OF THE SECRETARY OF AGRICULTURE, WITH THB COOPERATION OF THE ASSOCIATION OF AMERICAN AGRICULTCRAL COLLEGES AND EXPERIMENT STATIONS 


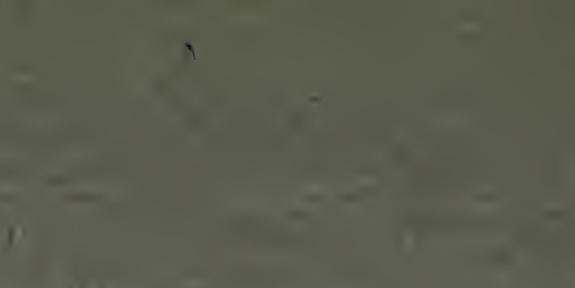

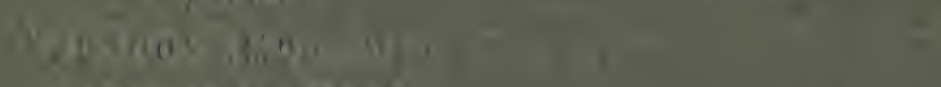

$\therefore$,

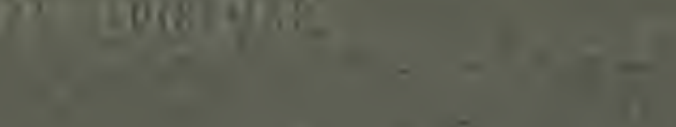

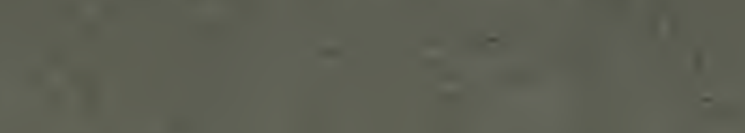

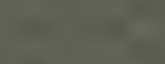

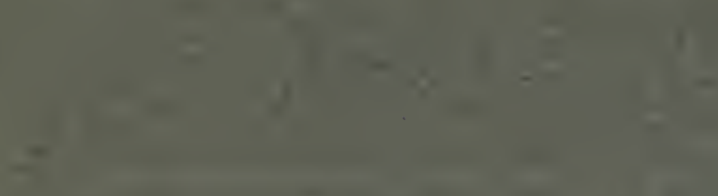

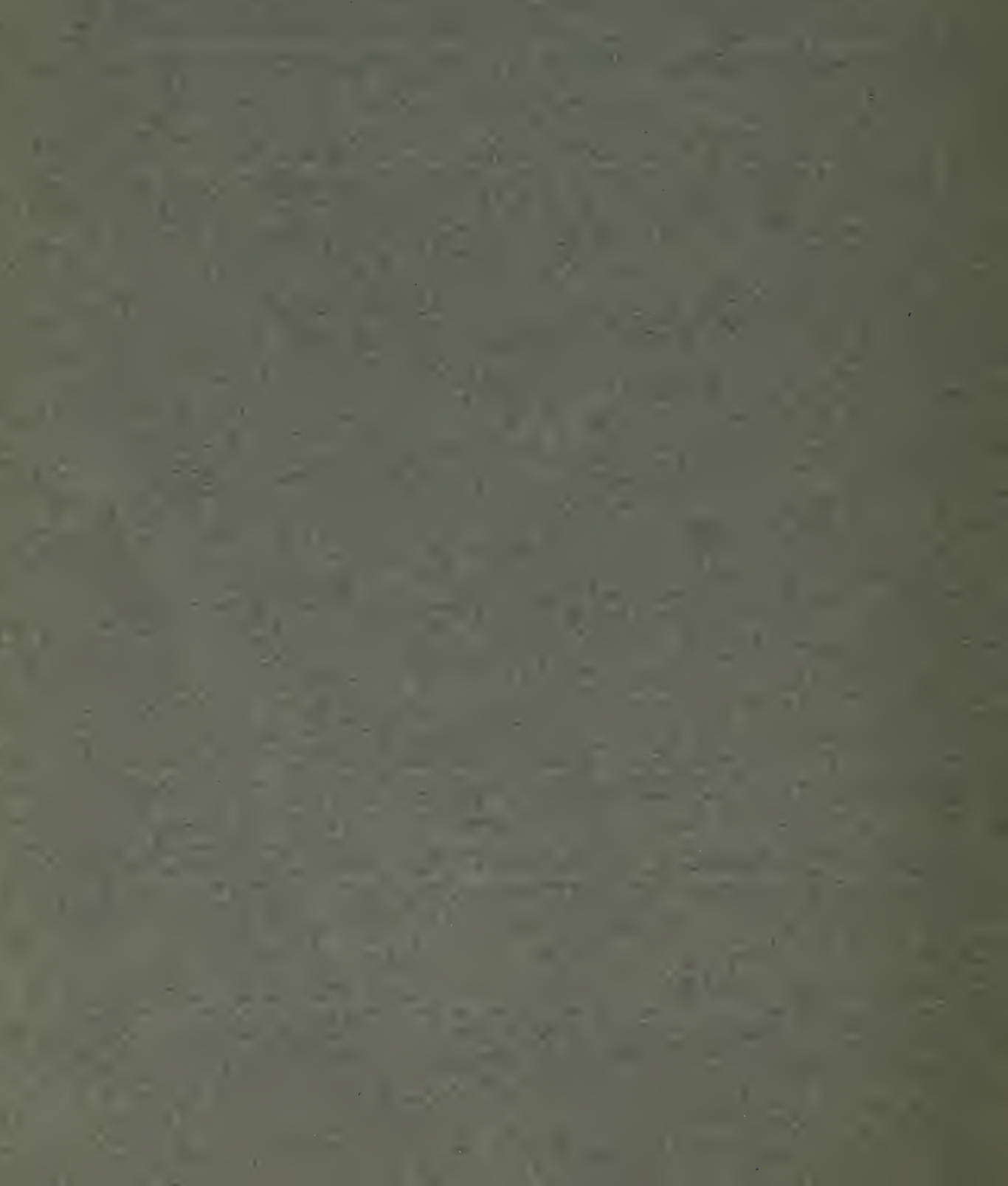




\title{
CORRELATION BETWEEN THE PERCENTAGE OF FAT IN COW'S MILK AND THE YIELD ${ }^{1}$
}

\author{
By ELMER ROBERTS \\ Instructor and First Assistant in Genetics, Agricultural Experiment Station, University \\ of Illinois
}

\section{INTRODUCTION}

It is a generally accepted opinion that cows with a large yield of milk produce a smaller percentage of fat than do cows with a small yield of milk. Stated in another way, it is thought that low-yielding cows produce a higher percentage of fat than that produced by high-yielding cows.

To what extent this is true or not true has not up to the present time been demonstrated by a careful statistical investigation. Wilson ${ }^{2}$ from a study of the records of 2,866 Ayrshire cows concluded that quantity and quality (yield of milk and percentage of fat) were independent of each other. He states:

If we group together all the low-yielding cows, and find their milk invariably high in quality, we may infer that low yield and high quality are of the nature of concomitant variations. If we group the high-yielding cows together, and find their milk invariably of low quality, we may infer that high yield and low quality run together. But if we take these groups and any other groups we can form, and find that the quality varies the same way in them all-that is that there are low qualities, high qualities, and medium qualities in every one of them - then we are justified in inferring that the quantity and quality of the milk are independent of each other. And this is what we do find.

In a criticism of this work Pearson, ${ }^{3}$ by means of a correlation table, showed that there was a small but significant decrease in the percentage of fat with an increase in the yield of milk, and pointed out the fallacy of such a process of reasoning in connection with statistical data.

\footnotetext{
1 Paper No. 5 from the Laboratory of Genetics, Agricultural Experiment Station of the University of Illinois.

2 WILSON, James. THE SEPARATE INHERITANCE OF QUANTITY AND QUALITY IN COWs' MILK. In Sci. Proc. Roy. Dublin Soc., n. S., v. 12, no. 33, p. 470 479, 6 diagr. I9ro.

3 Pearson, Karl. note on the separate inhertance of Quantity and Quality in cows' milk.
} In Biometrika, v. 7, No. 4, p. 548-550. Igro. 
Wilson did not handle his data in such a way as to bring out the relationship which exists between the quantity and quality. In "The Principles of Stock-Breeding," Wilson ${ }^{1}$ again writes:

In connection with yield and quality in milk, it has been assumed, frequently, that the two characters are interdependent: that when the one is high the other must be low. It has been found that this is not so. The characters are independent and have no effective influence upon each other. High quality of milk is found among cows giving all kinds of yield, and low quality is found similarly.

It seemed to the writer that it might be of some value to make a more careful statistical investigation of this question with our American cattle.

\section{SOURCE OF DATA}

In the registers of the different American associations is to be found a large body of data which furnished the major part of the material for this investigation. There are involved in this study the following: 2, I4I yearly tests of Jerseys, Register of Merit, I9I I, I9I3; 3,564 Guernseys, Guernsey Breeders' Journal, May, I9I5; I,925 HolsteinFriesians, Holstein-Friesian Advanced Register Year Book, volumes 2I-26; I,09I Ayrshires, Year Book of the Ayrshire Breeders' Association, I907, I9II, I9I3, I9I4; 98 Ayrshires $^{2} ; 750$ grade Jerseys ${ }^{3}$ and 34I grade Holstein-Friesians ${ }^{4}$; and $2,002^{4}$ yearly tests of cows unclassified as to breed.

Only the yearly tests were used for the reason that a yearly record is a more reliable criterion of a cow's performance and ability than a shorter test. It should be pointed out here, that in the case of the records from the associations, selected groups of individuals are involved in this study, since only selected individuals are subject to entry in the registers of the associations.

The method of finding the relation between the percentage of fat and the yield of milk is by means of the correlation table. The cows are grouped, according to age when the test began, into the following groups: 2 to 3 years, 3 to 4 years, 4 to 5 years, and 5 years and over. The last group comprises what are usually held to be mature cows. These are not exact divisions according to age, since a given group may contain individuals differing in age by almost a year. For example, the 3 -to-4-year group contains those cows with tests beginning at some time after they were 3 and before they were 4 years old. A cow with a test beginning the day she was 3 would be practically a year younger than one having a test starting when she was one day under 4 , though both would be classed in the same group. Of course, there are few cases of this kind.

1 WILSON, James. THE PRINCIPLES OF STOCK-BREEDING. p. I21-122. London, I9I2.

2 Furnished by Mr. C. M. Winslow, Secretary of the Ayrshire Breeders' Association.

${ }^{3}$ Obtained from Mr. W. W. Yapp, Illinois Agricultural Experiment Station.

- Obtained from Prof. W. J. Fraser, Illinois Agricultural Experiment Station. 


\section{POSSIBLE SOURCES OF ERROR}

In some of the breeds, Jersey and Guernsey, a yearly test consists of any 365 consecutive days. This may cover parts of two lactation periods, which is not a serious objection, since the study is interested in the relation between the percentage of butter fat and yield of milk in groups of individuals and not in the individual herself. In other words, the question is to what extent, if any, do cows with large milk yield tend to show a low percentage of fat, or cows with a low milk yield to show a high percentage. The Ayrshire Association specifies both the amount of milk and butter fat necessary for entrance. In the other associations only the butter-fat yield is specified. Unless the requirements of the Ayrshire Association are in accordance with the natural relation of butter-fat and milk yield, one would expect to find abnormal results in such a selected group, which would not hold for Ayrshire cattle in general. This point will be treated more fully later in this paper. For the grade Jerseys, grade Holstein-Friesians, and cows unclassified as to breed, it should be pointed out that the populations are composed of a heterogeneous lot, and whatever results are found will apply only to such mixed populations.

\section{ANALYSIS OF DATA}

\section{JERSEY}

Tables I to IV show, in the form of correlation tables, the distribution of individuals with regard to the yield of milk and the percentage of fat. Table $\mathrm{V}$ contains all the tests of Jerseys regardless of age and was made by combining Tables I to IV. Text Table A summarizes the means, standard deviations, coefficients of variability of milk and fat, and the correlation between the percentage of fat and the yield for Jerseys of different ages, and for Jerseys, irrespective of age.

TABLE A.- Summary of results from a study of the correlation between the percentage of fat and yield of milk for Jerseys

[Fat in percentage; milk in pounds]

\begin{tabular}{|c|c|c|c|c|c|c|}
\hline Age. & $\begin{array}{c}\text { Num- } \\
\text { ber of } \\
\text { animals. }\end{array}$ & $\begin{array}{l}\text { Type of } \\
\text { test. }\end{array}$ & Mean. & $\begin{array}{l}\text { Standard } \\
\text { deviation. }\end{array}$ & $\begin{array}{c}\text { Coefficient } \\
\text { of varia- } \\
\text { bility. }\end{array}$ & Correlation. \\
\hline $\begin{array}{c}\qquad \text { cars. } \\
2 \text { to } 3 \ldots \ldots \ldots \\
3 \text { to } 4 \ldots \ldots \\
4 \text { to } 5 \ldots \ldots \\
5 \text { and over...... } \\
\text { All ages........ }\end{array}$ & $\begin{array}{r}877 \\
4 I I \\
2 I 9 \\
634 \\
2, I 4 I\end{array}$ & $\begin{array}{l}\left\{\begin{array}{l}\text { Milk..... } \\
\text { Fat..... }\end{array}\right. \\
\left\{\begin{array}{l}\text { Milk.... } \\
\text { Fat..... }\end{array}\right. \\
\left\{\begin{array}{l}\text { Milk.... } \\
\text { Fat..... }\end{array}\right. \\
\left\{\begin{array}{l}\text { Milk.... } \\
\text { Fat..... }\end{array}\right. \\
\left\{\begin{array}{l}\text { Milk ..... } \\
\text { Fat..... }\end{array}\right.\end{array}$ & $\begin{array}{c}6,475 \cdot 0 \pm 28.9 \\
5 \cdot 425 \pm 0.012 \\
7,325 \cdot 0 \pm 45 \cdot 8 \\
5 \cdot 401 \pm 0.019 \\
8,043 \cdot 4 \pm 60.7 \\
5 \cdot 462 \pm 0.024 \\
8,814 \cdot 5 \pm 43.1 \\
5 \cdot 322 \pm 0.013 \\
7,491.4 \pm 25 \cdot 0 \\
5 \cdot 392 \pm 0.008\end{array}$ & $\begin{array}{c}x, 270.5 \pm 20.5 \\
0.517 \pm 0.008 \\
1,377.5 \pm 32.4 \\
0.562 \pm 0.013 \\
x, 332.5 \pm 42.9 \\
0.533 \pm 0.017 \\
x, 608.5 \pm 30.5 \\
0.502 \pm 0.010 \\
x, 718.0 \pm 17.7 \\
0.525 \pm 0.005\end{array}$ & $\begin{array}{r}19.62 \pm 0.33 \\
9.52 \pm 0.15 \\
18.81 \pm 0.46 \\
10.41 \pm 0.25 \\
16.57 \pm 0.55 \\
9.76 \pm 0.32 \\
18.25 \pm 0.35 \\
9.44 \pm 0.18 \\
22.93 \pm 0.25 \\
9.74 \pm 0.10\end{array}$ & $\begin{array}{l}-0.360 \pm 0.020 \\
-0.437 \pm 0.027 \\
-0.359 \pm 0.040 \\
-0.397 \pm 0.023 \\
-0.354 \pm 0.01_{3}\end{array}$ \\
\hline
\end{tabular}


The correlation is negative and very significant for all ages. When judged by their probable errors, there are no significant differences among the correlations for the different groups.

The milk yield increases from an average of 6,475 pounds for the 2-to3-year-old class to $8,8 \mathrm{I} 4.5$ pounds for the mature class (fig. I). Since

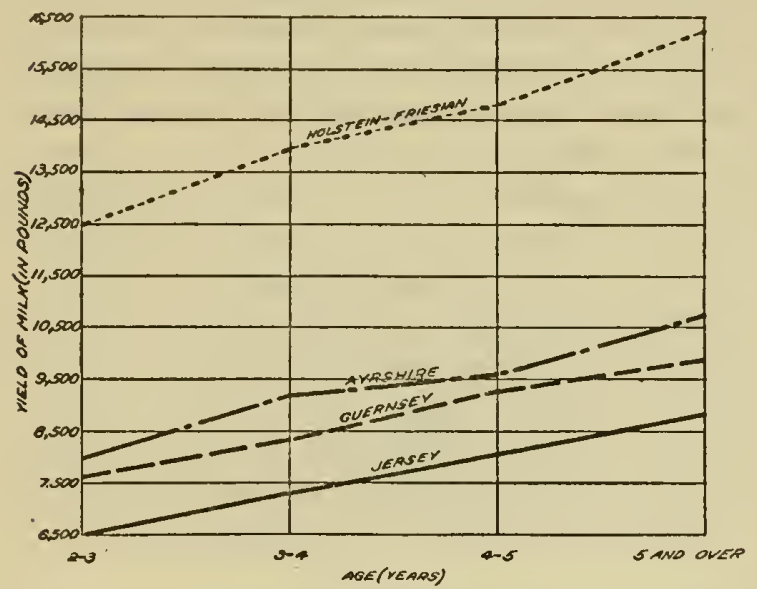

Fig. x.-Graphs showing the averages of the milk yield for the different ages of cows. there is a marked negative correlation between the percentage of fat and yield at all ages, one might look for the percentage of fat to decrease as the yield of milk increases with the age of the cows. The class which is 5 years and over shows a slightly smaller percentage of fat, but the 4-to-5-year-old class has a higher percentage than the 3-to-4-year-old class, though the difference is not significant (fig. 2). On the whole, the percentage remains practically the same. This may be due to the relatively stable relation between the amount of fat and yield throughout the growing period of the individual cow. Holdaway ${ }^{1}$ found this to be true for Holstein-Friesians, using the 7 -day records. Stated in another way, the percentage of fat seems to be fairly constant throughout the life of a given individ. ual, but different individuals show differing percentages of fat. The results show that at a given age cows with a high milk yield tend to produce a lower percentage of

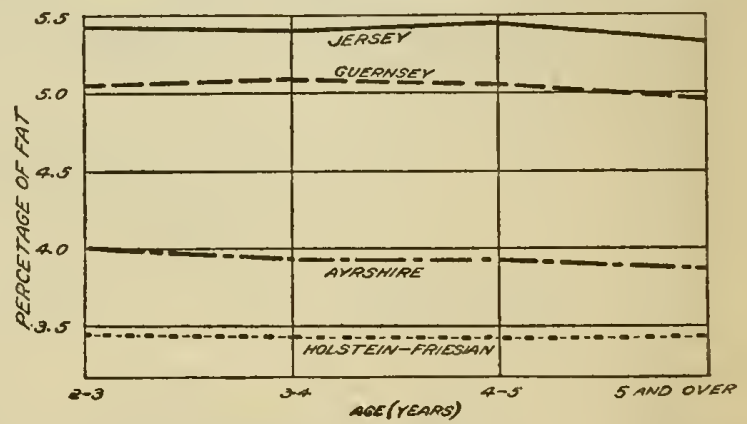

Fig. 2.-Graphs showing the averages of percentages of butter fat for different breeds of cows.

fat than do cows with a low milk yield. This is expressed by the negative correlations obtained. Table B illustrates in another way that this is true. This table is the result of arbitrarily dividing Table II into three parts, cows yielding 4,500 to 6,500 , those yielding 7,000 to 9,000 ,

\footnotetext{
I HOLDAWAY, C. W. STATISTICAL WEIGHIING FOR AGE OF ADVANCED REgistry COWS. In Amet. Nat., v. 50, no. 599, p. 676-687, 2 fig. 1916.
} 
and those yielding 9,500 to 13,000 pounds of milk, and finding the average yield of milk and percentage of fat. 'The decrease from 5.657 per cent for the first group to $4.94 \mathrm{I}$ per cent for the third group is very significant. Any group of cows showing a negative correlation between percentage of fat and yield of milk would give, in general, the same results if treated as was Table II.

TABLE B.-Milk yield and percentage of butter fat of Jerseys 3 to 4 years of age

\begin{tabular}{|c|c|c|c|}
\hline Number of animals. & $\begin{array}{c}\text { Extremes of milk } \\
\text { yield. }\end{array}$ & $\begin{array}{l}\text { Average milk } \\
\text { yield. }\end{array}$ & $\begin{array}{l}\text { Average per- } \\
\text { centage of fat. }\end{array}$ \\
\hline $\begin{array}{r}152 \ldots \ldots \ldots \\
220 \ldots \ldots \\
39 \ldots \ldots\end{array}$ & $\begin{array}{l}\text { Pounds. } \\
4,500-6,500 \\
7,000-9,000 \\
9,500-13,000\end{array}$ & $\begin{array}{r}\text { Pounds. } \\
6,049 \cdot 3 \\
7,677 \cdot 3 \\
\text { I0, 307.7 }\end{array}$ & $\begin{array}{l}5.657 \\
5.307 \\
4.94 I\end{array}$ \\
\hline
\end{tabular}

\section{GUERNSE Y}

Tables VI to IX show the distribution of individuals with regard to the yield of milk and the percentage of butter fat, in the form of correlation tables. Table $\mathrm{X}$ combines Tables. VI to IX. Table $\mathrm{C}$ gives the means, standard deviations, coefficients of variability of milk and fat, and the correlation between the percentage of fat and yield of milk for Guernseys of different ages.

TABLE C.-Summary of results from a study of the correlation between the percentage of fat and yield of milk for Guernseys

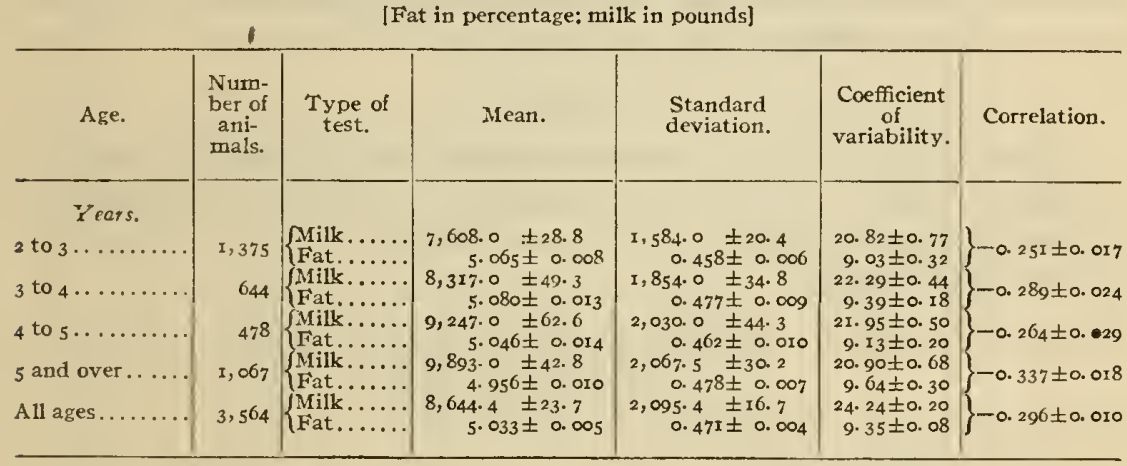

The correlation coefficients are negative as in the case of the Jerseys, but slightly smaller. For the Jerseys they range from $-0.359 \pm 0.040$ to $-0.437 \pm 0.027$, while for the Guernseys the range is from $-0.251 \pm 0.017$ to $-0.337 \pm 0.018$. The yield of milk gradually increases from an average of 7,608 pounds for the 2-to-3-year-old class to 9,893 for the group which is 5 years and over. The average percentage of fat varies from $4.956 \pm 0.010$ for the group which is 5 years and over to $5.080 \pm 0.013$ for the 3-to-4-year-old class. (See fig. 2.) 


\section{HOLSTEIN-FRIESIAN}

Tables XI to XIV exhibit the distributions of individuals with regard to the yield of milk and the percentage of fat in the form of correlation tables. Table XV combines Tables XI to XIV. Table D summarizes the means, standard deviations, coefficients of variability for milk and fat, and the correlations between percentage of fat and yield for $\mathrm{Hol}$ stein-Friesians of different ages.

TABLE D.-Summary of results from a study of the correlation between the percentage of fat and yield of milk for Holstein-Friesians

[Fat in percentage; ruilk in pounds]

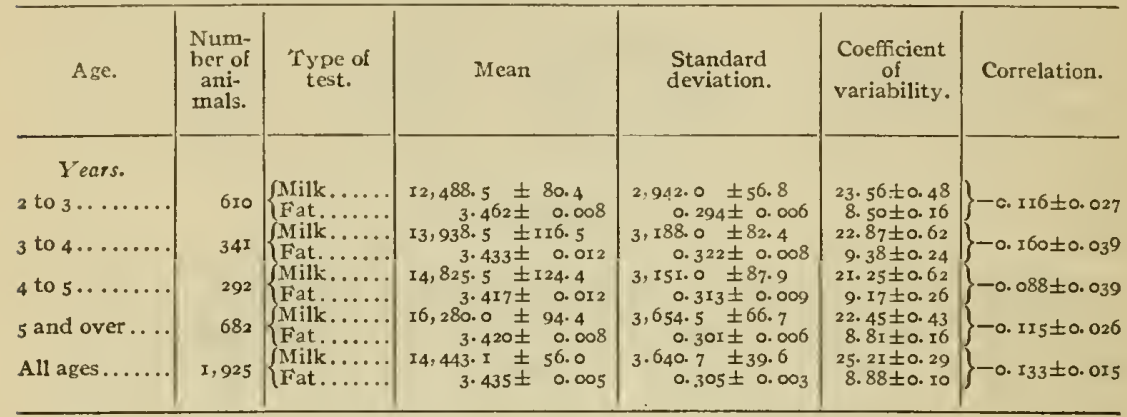

The correlations are much smaller for the Holstein-Friesian than for the two preceding breeds. They range from $-0.088 \pm 0.039$ to $-0.160 \pm$ 0.036 . The first is not significant when judged by the probable error. The milk yields increase regularly from 12,488 pounds for the youngest class to $I 6,280$ for the oldest. The percentages of fat remain practically constant for the different ages. (See fig. 2.)

1

\section{AYRSHIRE}

Tables XVI to XIX are correlation tables for the different classes of Ayrshires. 'Table E gives means, standards deviations, coefficients of variability for milk and fat, and the correlations between percentages of fat and yield of milk.

TABLE E.-Summary of results from a study of the correlation between the percentage of fat and yield of milk for A yrshires

[Fat in percentage: milk in pounds]

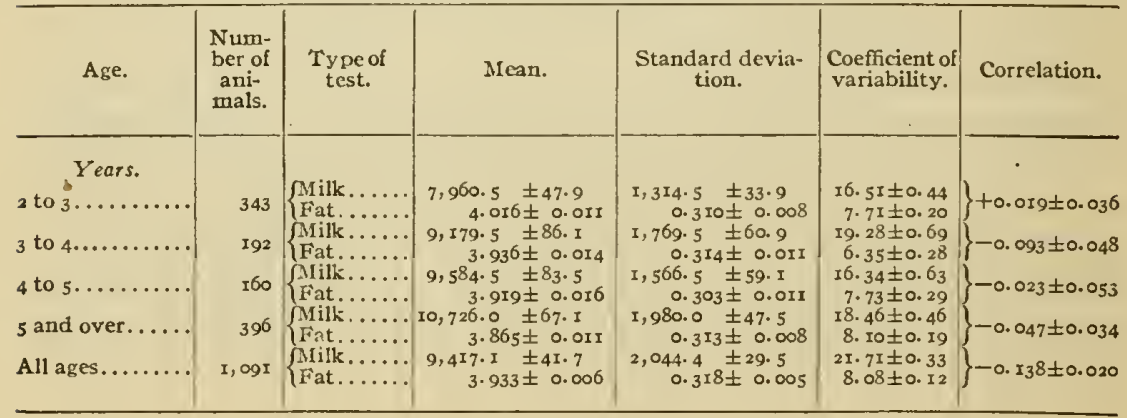


In no one of the four groups classified as to age is there a significant correlation, meaning that for these classes of individuals studied the milk yield and percentage of fat are independent. It is curious that this breed should have a different relation existing between fat and milk than that of the Jerseys, Guernseys, and Holstein-Friesians. This result is probably due to the fact that they are a much more highly selected group of individuals than in the case of any of the other breeds, owing to the requirements for registry imposed by the Ayrshire Association. The minimum requirements are as follows:

\begin{tabular}{|c|c|c|}
\hline Age. & Weight of milk. & Weight of fat. \\
\hline 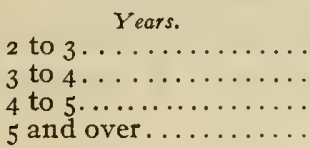 & $\begin{array}{r}\text { Pounds. } \\
6,000 \\
6,500 \\
7,500 \\
8,500\end{array}$ & $\begin{array}{l}\text { Pounds. } \\
214.3 \\
236.0 \\
279.0 \\
322.0\end{array}$ \\
\hline
\end{tabular}

This would mean that upon the basis of these specified amounts the percentages of fat for the different ages would be as follows:

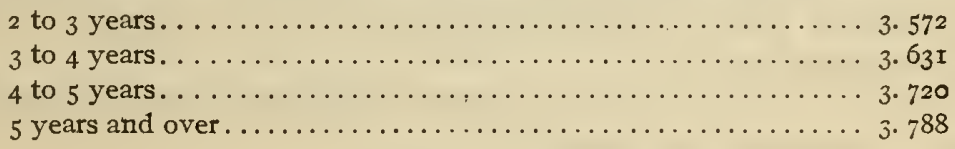

A gradual increase in the percentage of fat as the age increases is to be noted. This is contrary to what was found to exist for the other breeds. For Table XX, constructed from Tables XVI to XIX, a correlation of $-0.138 \pm 0.020$ is found. This is practically the same correlation found for the Holstein-Friesian cows. This negative correlation resulting from combining the subgroups of Ayrshires is to be expected, since there is an increase in the milk yield with age and a decrease in the percentage of fat. (See Table E.) It may be that the requirements for entry in the register of the Ayrshire Association tend to eliminate high-yielding cows with a low percentage of fat and low-yielding cows with a high percentage of fat.

The correlation between the yield and percentage of fat for $98 \mathrm{Ayr}-$ shire cows which were tested and failed to meet the requirements was found tờ be

$$
r=-0.226 \pm 0.065 \text {. }
$$

A larger number of such tests would be necessary to determine whether a difference exists between cows which meet the requirements and those which do not. 
The percentage of butter fat among these 98 tests decreases with age as in Table E, as follows:

\begin{tabular}{|c|c|c|}
\hline $\begin{array}{c}\text { Number of } \\
\text { auimals. }\end{array}$ & Age. & $\begin{array}{c}\text { Percentage } \\
\text { of fat. }\end{array}$ \\
\cline { 1 - 2 } I9 & 2 to $3 \ldots \ldots \ldots \ldots$ & 4. II2 \\
22 & 3 to $4 \ldots \ldots \ldots$ & 4.035 \\
20 & 4 to $5 \ldots \ldots \ldots$ & 3.997 \\
37 & 5 and over.... & 3.842 \\
\hline
\end{tabular}

The work of Speir ${ }^{1}$ shows that there is a slight tendency for the percentage of fat to decrease in Ayrshires after the third year. Both Jerseys and Guernseys of 5 years of age and over show a slight decrease (See Tables A and B.) The mature class of Holstein-Friesian cows, however, does not show a decrease (Table C).

\section{COWS NOT PURE-BRED}

The writer thought it would be of interest to see the extent of correlation between the yield and percentage of fat in cows not pure-bred. Grade Jerseys, grade Holsteins-Friesians, and cows unclassified as to breed are considered.

Tables $F, G$, and $H$ give the results of the study for the different classes in the order given above.

TABLE F.-Summary of results from a study of the correlation between the percentage of fat and yield of milk for grade Jerseys

[Fat in percentage; milk in pounds]

\begin{tabular}{|c|c|c|c|c|c|c|}
\hline Age. & $\begin{array}{c}\text { Num- } \\
\text { ber of } \\
\text { animals. }\end{array}$ & $\begin{array}{c}\text { Type of } \\
\text { test. }\end{array}$ & Mean. & $\begin{array}{l}\text { Standard } \\
\text { deviation. }\end{array}$ & $\begin{array}{c}\text { Coefficient } \\
\text { of } \\
\text { variability. }\end{array}$ & Correlation. \\
\hline $\begin{array}{c}\qquad \text { Years. } \\
=\text { to } 3 \ldots \ldots \ldots \\
3 \text { to } 4 \ldots \ldots \ldots \\
4 \text { to } 5 \ldots \ldots . \\
5 \text { and over..... }\end{array}$ & $\begin{array}{l}101 \ldots \\
155 \ldots \\
146 \ldots \\
348 \ldots\end{array}$ & 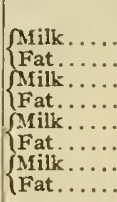 & $\begin{array}{c}4,663 \cdot 5 \pm 81 \cdot 7 \\
5 \cdot 106 \pm 0.033 \\
5,035 \cdot 5 \pm 71 \cdot 3 \\
5 \cdot 124 \pm 0.023 \\
5,298.0 \pm 71 \cdot 5 \\
5 \cdot 068 \pm 0.029 \\
5,504 \cdot 5 \pm 48.1 \\
4.923 \pm 0.022\end{array}$ & $\begin{array}{c}1,217.0 \pm 57.8 \\
0.489 \pm 0.023 \\
I, 316.0 \pm 50.4 \\
0.592 \pm 0.023 \\
I, 281.5 \pm 50.6 \\
0.520 \pm 0.021 \\
1,329.0 \pm 34.0 \\
0.606 \pm 0.016\end{array}$ & $\begin{array}{r}26.10 \pm 1.32 \\
9.57 \pm 0.45 \\
26.13 \pm 1.07 \\
11.56 \pm 0.45 \\
24.19 \pm 1.01 \\
10.26 \pm 0.41 \\
24.14 \pm 0.65 \\
12.32 \pm 0.32\end{array}$ & $\left\{\begin{array}{l}-0.114 \pm 0.066 \\
-0.234 \pm 0.051 \\
-0.272 \pm 0.052 \\
-0.138 \pm 0.035\end{array}\right.$ \\
\hline
\end{tabular}

I SPEIR, John. MILE REcords. In Trans. Highland and Agr. Soc. Scotland, S. 5, v. I6, p. 170-229, fig. 18-20. 1904. 
TABLE, G.-Summary of results from a study of the correlation between the percentage of fat and yield of milk for grade Holstein-Friesians

- [Fat in percentage; milk in pounds]

\begin{tabular}{|c|c|c|c|c|c|c|}
\hline Age. & $\begin{array}{c}\text { Num- } \\
\text { ber of } \\
\text { animals. }\end{array}$ & $\begin{array}{c}\text { Type of } \\
\text { test. }\end{array}$ & Mean. & $\begin{array}{l}\text { Standard } \\
\text { deviation. }\end{array}$ & $\begin{array}{c}\text { Coefficient } \\
\text { of } \\
\text { variability. }\end{array}$ & Correlation. \\
\hline $\begin{array}{c}\qquad \text { Years. } \\
\text { s to } 3 \ldots \ldots \ldots \\
3 \text { to } 4 \ldots \ldots \ldots \\
4 \text { to } 5 \ldots \ldots \ldots \\
s \text { and over..... }\end{array}$ & $\begin{array}{l}76 \ldots \\
88 \ldots \\
41 \ldots \\
136 \ldots\end{array}$ & 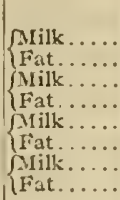 & $\begin{array}{c}5,776.5 \pm I I 3.4 \\
3.688 \pm 0.028 \\
6,727.5 \pm I 12.1 \\
3.563 \pm 0.025 \\
7,305.0 \pm 214.8 \\
3.581 \pm 0.041 \\
7,441.0 \pm 104.1 \\
3.546 \pm 0.025\end{array}$ & $\begin{array}{c}1,465.5 \pm 80.2 \\
0.361 \pm 0.020 \\
1,559.0 \pm 79.3 \\
0.344 \pm 0.018 \\
2,039.5 \pm 151.9 \\
0.391 \pm 0.029 \\
1,799.0 \pm 73.6 \\
0.440 \pm 0.018\end{array}$ & $\begin{array}{r}25.37 \pm 1.48 \\
9.80 \pm 0.54 \\
23.17 \pm 1.24 \\
9.64 \pm 0.49 \\
27.92 \pm 2.23 \\
10.92 \pm 0.82 \\
24.18 \pm 1.05 \\
12.39 \pm 0.51\end{array}$ & $\left\{\begin{array}{l}-0.211 \pm 0.074 \\
-0.345 \pm 0.063 \\
-0.155 \pm 0.103 \\
-0.212 \pm 0.053\end{array}\right.$ \\
\hline
\end{tabular}

TABLE H.-Summary of results from a study of the correlation between the percentage of fat and yield of milk for cous unclassified as to breed

[Fat in percentage; milk in pounds]

\begin{tabular}{|c|c|c|c|c|c|c|}
\hline Age. & $\begin{array}{c}\text { Num- } \\
\text { ber of } \\
\text { animals. }\end{array}$ & $\begin{array}{l}\text { Type of } \\
\text { test. }\end{array}$ & Mean. & $\begin{array}{l}\text { Standard } \\
\text { deviation. }\end{array}$ & $\begin{array}{c}\text { Coefficient } \\
\text { of } \\
\text { variability. }\end{array}$ & Correlation. \\
\hline All ages. & $2,002 \ldots$ & $\left\{\begin{array}{l}\text { Milk..... } \\
\text { Fat...... }\end{array}\right.$ & $\begin{array}{r}5,824.6 \pm 28.5 \\
3.902 \pm 0.009\end{array}$ & $\begin{array}{l}\mathbf{I}, 883.2 \text { 土20. I } \\
0.575 \pm 0.006\end{array}$ & $\begin{array}{l}32.42 \pm 0.38 \\
14.75 \pm 0.16\end{array}$ & $-0.359 \pm 0$ \\
\hline
\end{tabular}

There is a very significant negative correlation between the yield and percentage of fat for all three classes of cows represented by the three foregoing tables (Tables $\mathrm{F}-\mathrm{H}$ ).

\section{CONCLUSIONS}

(1) A significant negative correlation exists between the percentage of fat in cows' milk and the yield for the Jerseys, Guernseys, HolsteinFriesians, grade Jerseys, grade Holstein-Friesians, and cows unclassified as to breed. The correlation for Ayrshires is not significant in the subgroups classed in respect to age, but it is significant when these groups are treated as a whole. (See Tables XXI and F, G, H.)

(2) The yield of milk increases with age. However, since all cows 5 years of age and over are classed together, it may well be that the yield decreases at some period beyond 5 years. Pearl and Patterson ${ }^{1}$ showed that in Jersey cows using the 7 -day records that the maximum production is reached between the eighth and ninth year. Crowther ${ }^{2}$ from records of Ayrshires is of the opinion that maximum production is close to the eighth year. (See Table XXI and fig. I.)

(3) In the Jerseys, Guernseys, and Holstein-Friesians the percentage of fat remains fairly constant for the different ages studied. However,

\footnotetext{
I PEARL, Raymond, and PATTERSON, S. W. THE CHANGE, OF MILK FLOW WITH AGE, AS DETERITNED FROM THE SEVEN-DAY RECOROS OF JERSEY COWS. Maine Agt. Exp. Sta. Bul. 262, p. 145-152, fig. 7 . I917.

Crowther, Charles. VARIATION IN THE composition OF cow's Mirk. In Jour. Agr. Sci., v. I, pt. 2, P. $149-175.1905$.
} 
the group 5 years of age and over in the Jerseys and Guernseys shows a slightly lower percentage of fat than the younger groups. In the case of the Ayrshires, there is a gradual decrease with age. Between the youngest and oldest groups there is a difference of o.I $5^{I}$ per cent. (See Table XXI and fig. 2.)

(4) When judged by the standard deviation, age has no influence on the variability of the percentage of butter fat. But the class 5 years of age and over is more variable in the yield of milk than the younger groups. This may occur because of the inclusion in this group of old cows whose milk yield has decreased. (See Table XXI.)

(5) The breed has an influence on the variability of milk yield and percentage of fat, using the standard deviation as a basis of comparison. For variability in yield the breeds stand in the following order in an ascending scale: Jersey, Ayrshire, and Guernsey practically the same, Holstein-Friesian. For percentage of fat, the order is: Holstein-Friesian and Ayrshire about the same, Guernsey, Jersey. (See Table XXI.)

(6) For the production of milk the breeds stand as follows (see Table XXI.)

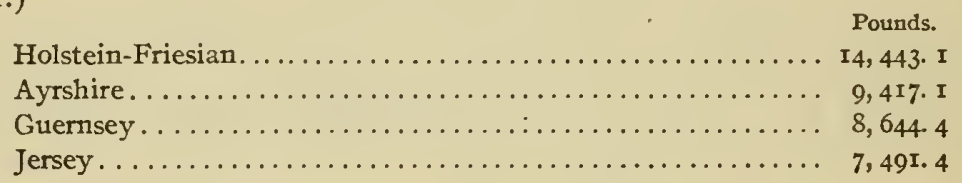

(7) The average percentages of fat for the different breeds are as follows (see 'Table XXI.)

Jersey.................................. 5. 392

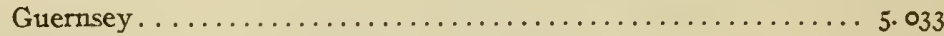

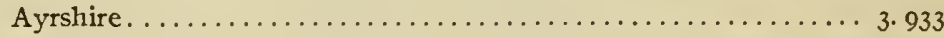

Holstein-Friesian.............................. 435 


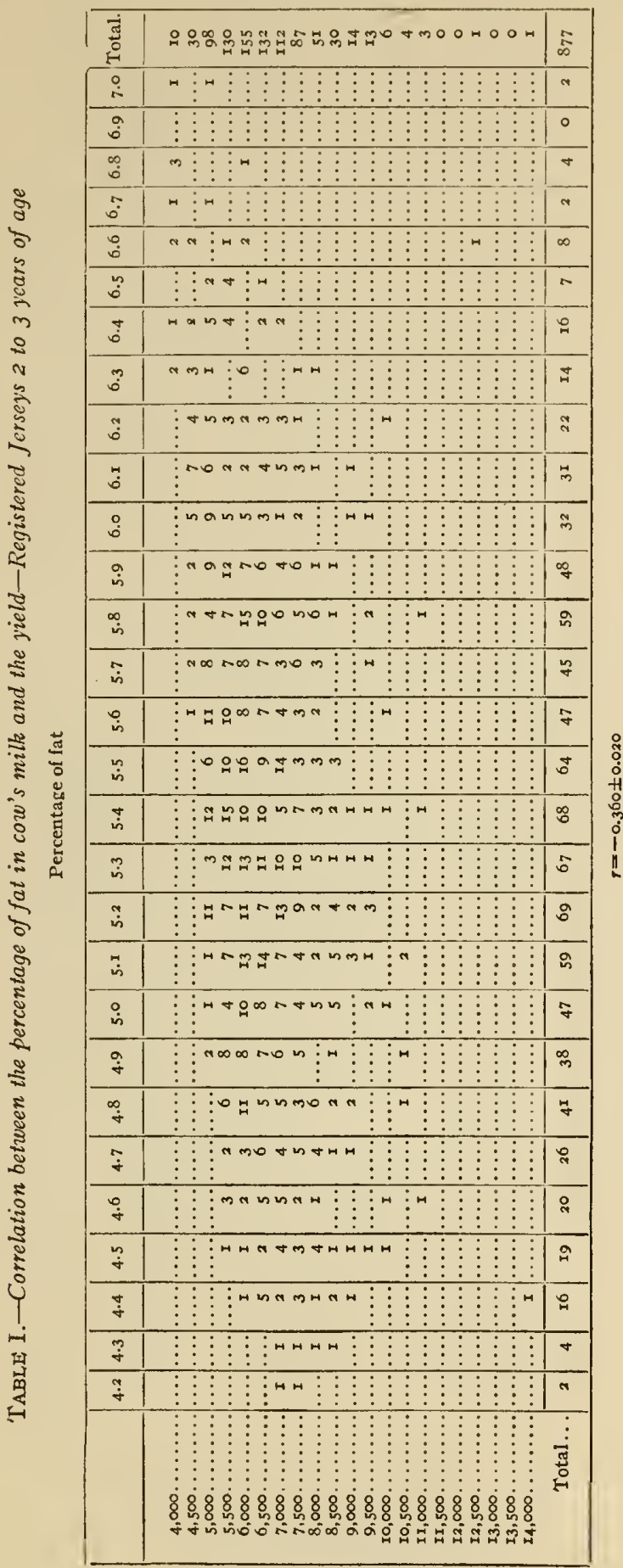

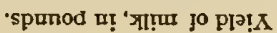




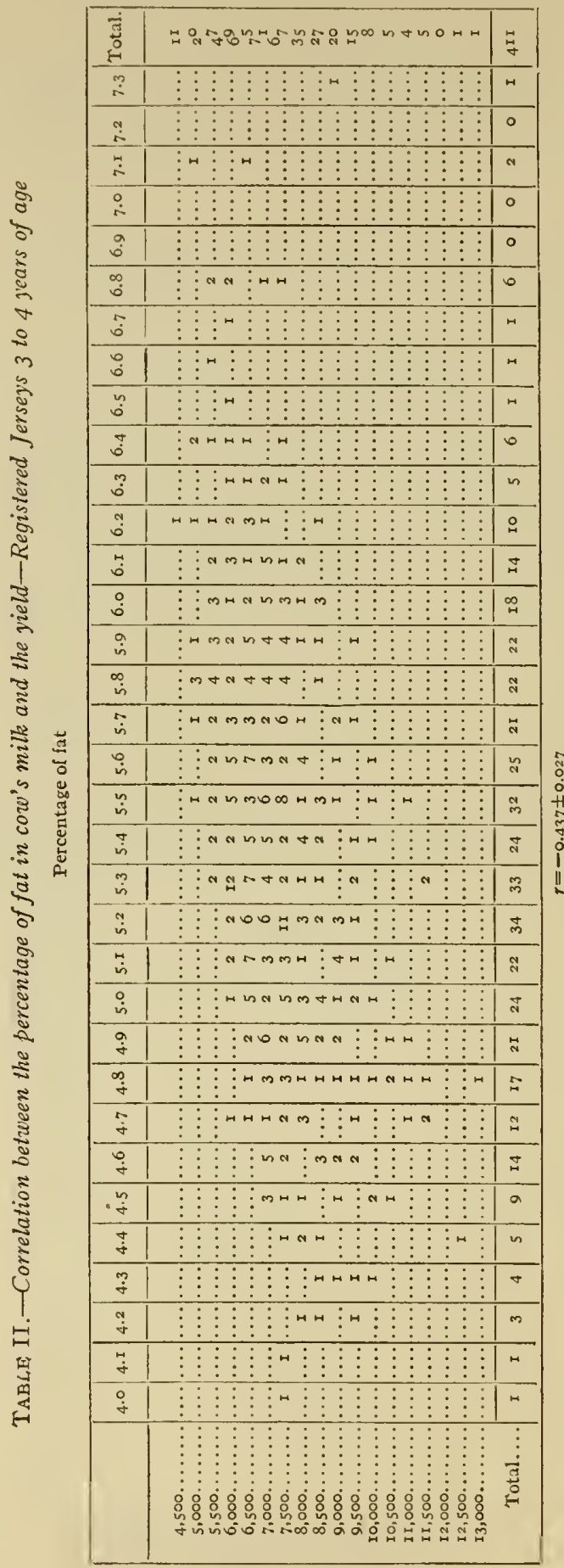

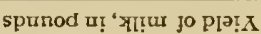




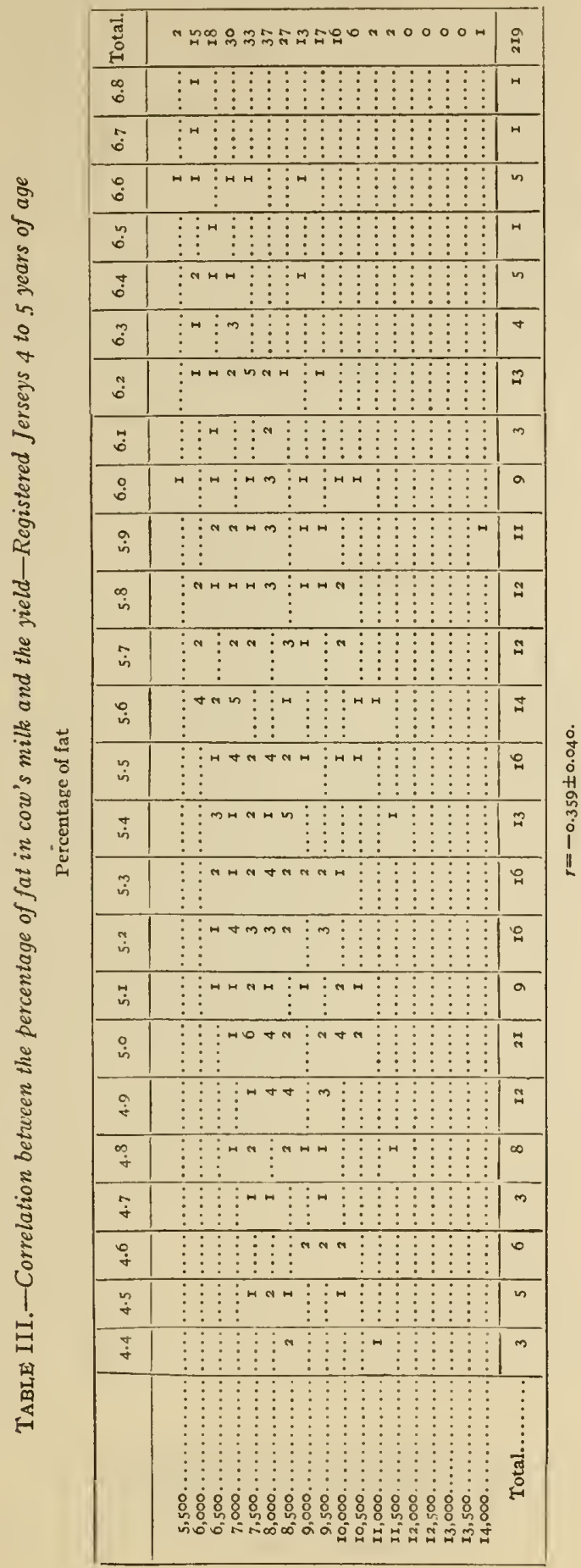

spunod u! 'भ!!แ jo plə! 


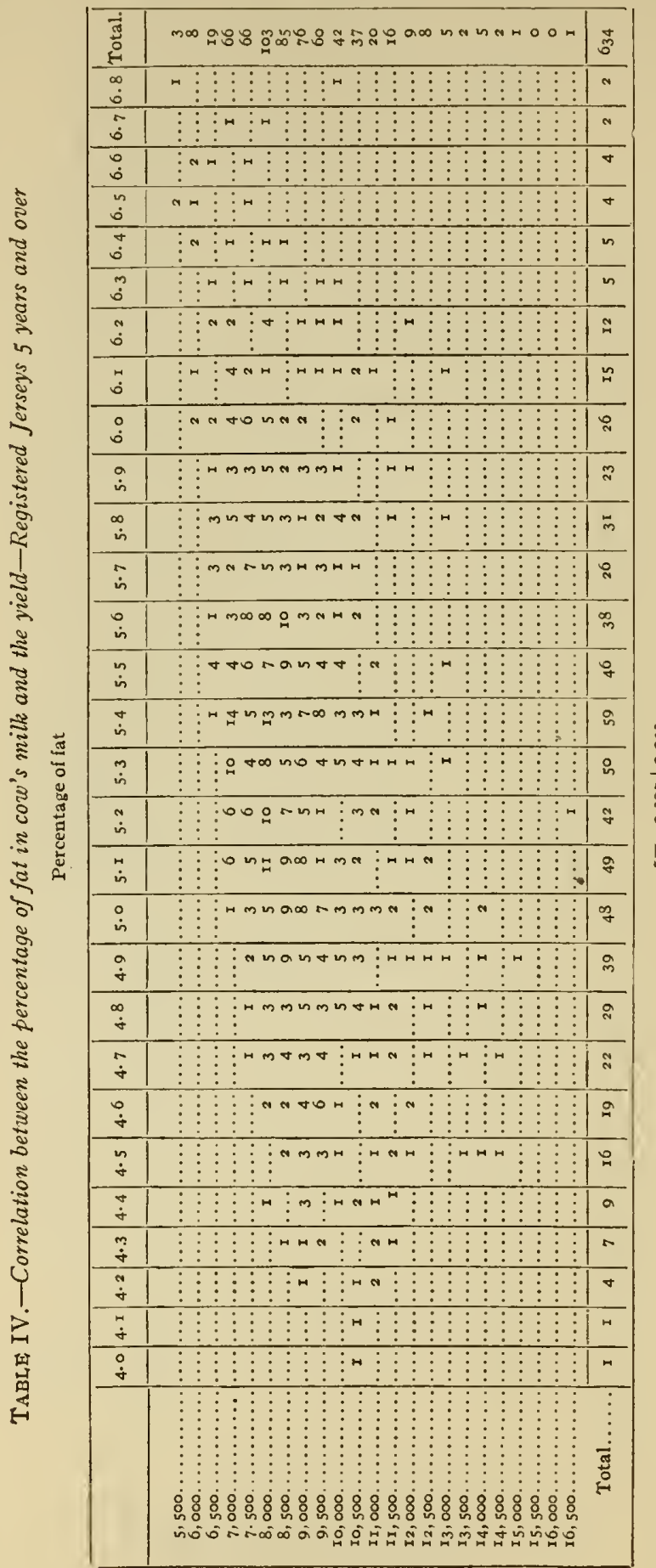

spunod u! ' 'भा!w jo pla!x 


\begin{tabular}{|c|c|c|c|}
\hline & ปี่ & 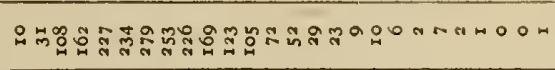 & $\underset{7}{7}$ \\
\hline & $\ddot{i}$ & $\vdots \vdots \vdots \vdots \vdots: \vdots \vdots \vdots \mu \vdots \vdots \vdots \vdots \vdots \vdots$ & $H$ \\
\hline & $\stackrel{9}{i}$ & $\vdots \vdots \vdots \vdots \vdots \vdots \vdots \vdots \vdots \vdots \vdots \vdots \vdots \vdots \vdots \vdots \vdots \vdots \vdots \vdots \vdots \vdots \vdots \vdots$ & $\circ$ \\
\hline & $\stackrel{5}{2}$ & $\vdots \vdots-\vdots \cdots \vdots \vdots \vdots \vdots \vdots \vdots \vdots \vdots \vdots \vdots \vdots \vdots \vdots \vdots \vdots \vdots \vdots$ & 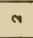 \\
\hline & 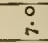 & $\sim \vdots \mu \vdots \vdots \vdots \vdots \vdots \vdots \vdots \vdots \vdots \vdots \vdots \vdots \vdots \vdots \vdots \vdots \vdots \vdots \vdots \vdots \vdots \vdots$ & N \\
\hline & $\dot{0}$ & $\vdots \vdots \vdots \vdots \vdots \vdots \vdots \vdots \vdots \vdots \vdots \vdots \vdots \vdots \vdots \vdots \vdots \vdots \vdots \vdots \vdots \vdots$ & $\circ$ \\
\hline & $\stackrel{\infty}{0}$ & 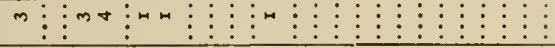 & $m$ \\
\hline & i & 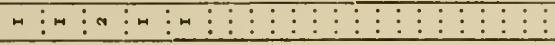 & $\circ$ \\
\hline & $\stackrel{0}{0}$ & 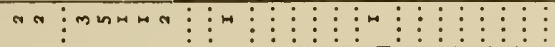 & $\stackrel{\infty}{H}$ \\
\hline & $\stackrel{n}{0}$ & 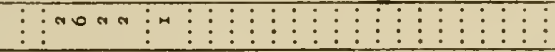 & $m$ \\
\hline & ì & 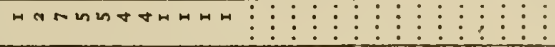 & is \\
\hline & $b^{3}$ & 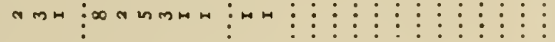 & $\stackrel{\infty}{\infty}$ \\
\hline & iี & 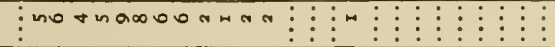 & in \\
\hline & $\stackrel{H}{0}$ & $\vdots$ MO+ー০ & $\ddot{0}$ \\
\hline & $\stackrel{0}{\circ}$ & 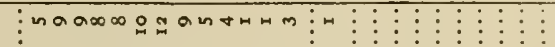 & $\varkappa$ \\
\hline & $\stackrel{a}{\dot{m}}$ & 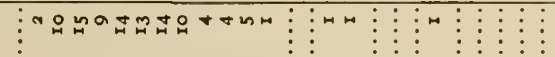 & 苟 \\
\hline & $\stackrel{\infty}{i}$ & 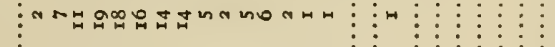 & $\stackrel{4}{a}$ \\
\hline & $\overline{\text { in }}$ & mgana & ষ্口 \\
\hline ज्ञ & $\stackrel{0}{i}$ & 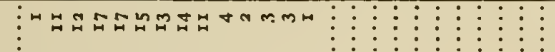 & $\stackrel{4}{\pi}$ \\
\hline छे & $\ddot{m}$ & 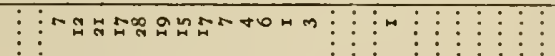 & $\underset{\substack{\infty \\
\sim}}{\sim}$ \\
\hline 预 & $\dot{I}$ & 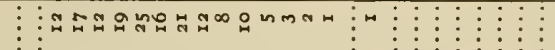 & ¿ \\
\hline 4 & $\ddot{m}$ & osaaao & 8 \\
\hline & $\dot{n}$ & 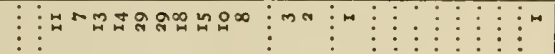 & 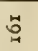 \\
\hline & $\dot{m}$ & 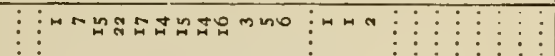 & $\stackrel{2}{\vec{w}}$ \\
\hline & $\stackrel{\circ}{\text { in }}$ & 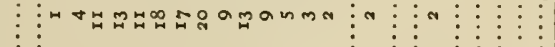 & $\stackrel{9}{\frac{9}{4}}$ \\
\hline & $\stackrel{a}{+}$ & 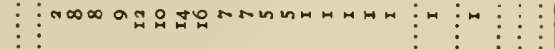 & $\stackrel{9}{\circ}$ \\
\hline & $\stackrel{\infty}{\dot{q}}$ & $\vdots \vdots \vdots$ 幺o & $\approx$ \\
\hline & $\check{\dot{q}}$ & 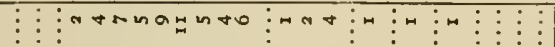 & 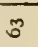 \\
\hline & $\stackrel{0}{\circ}$ & 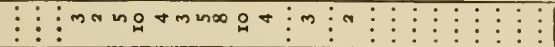 & 蚛 \\
\hline & $\ddot{+}$ & 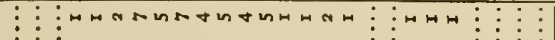 & \% \\
\hline & $\stackrel{+}{\dot{q}}$ & 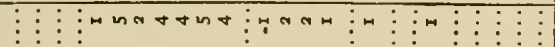 & $m$ \\
\hline & $\stackrel{m}{q}$ & 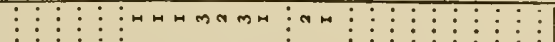 & $\approx$ \\
\hline & $\dot{4}$ & $\vdots \vdots \vdots \vdots \vdots$ ! & $a$ \\
\hline & $\dot{i}$ & $\vdots \vdots \vdots \vdots \vdots \vdots \sim \vdots \vdots \vdots \vdots \cdots \vdots \vdots \vdots \vdots \vdots \vdots \vdots \vdots \vdots \vdots \vdots$ & $a$ \\
\hline & $\stackrel{\circ}{+}$ & $\vdots \vdots \vdots \vdots \vdots \vdots+\vdots \vdots \vdots \vdots w \vdots \vdots \vdots \vdots \vdots \vdots \vdots \vdots \vdots \vdots \vdots$ & a \\
\hline & & 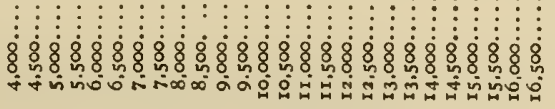 & 㐫 \\
\hline
\end{tabular}




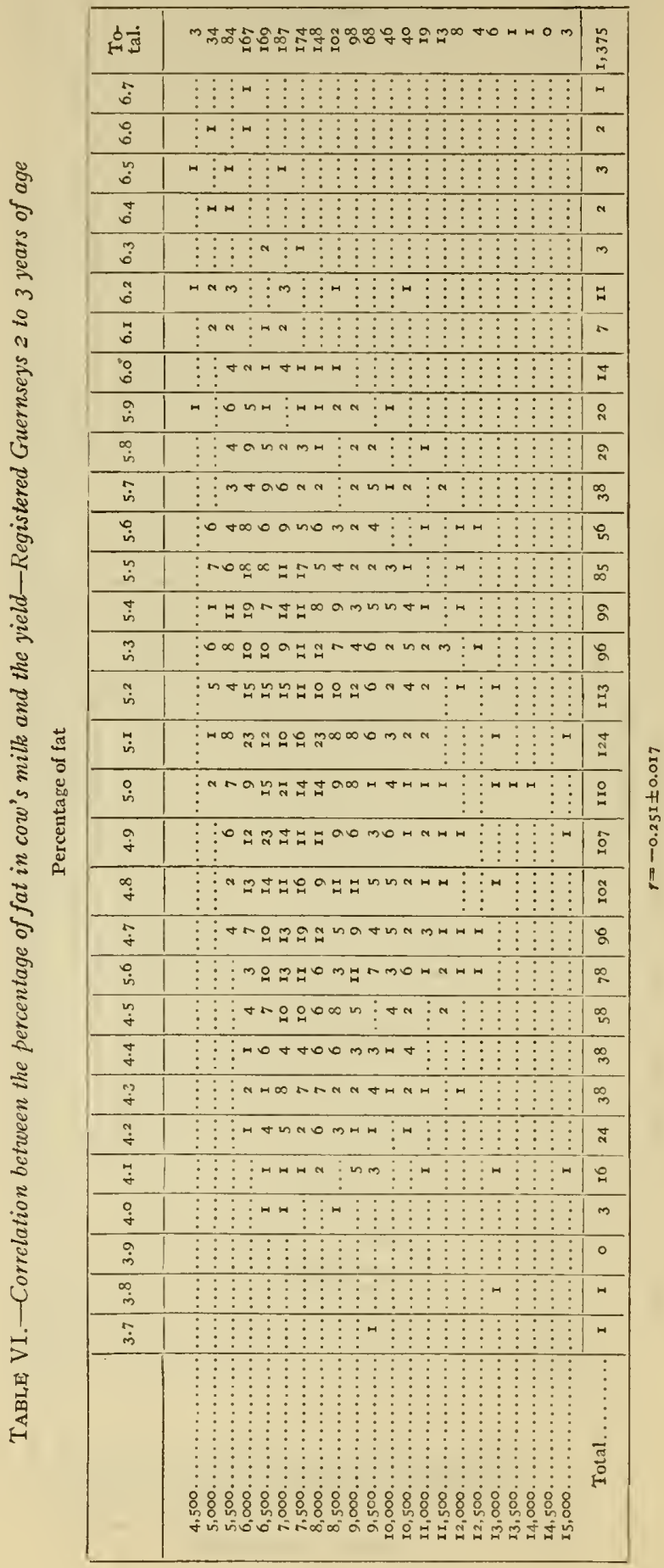

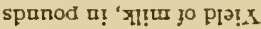




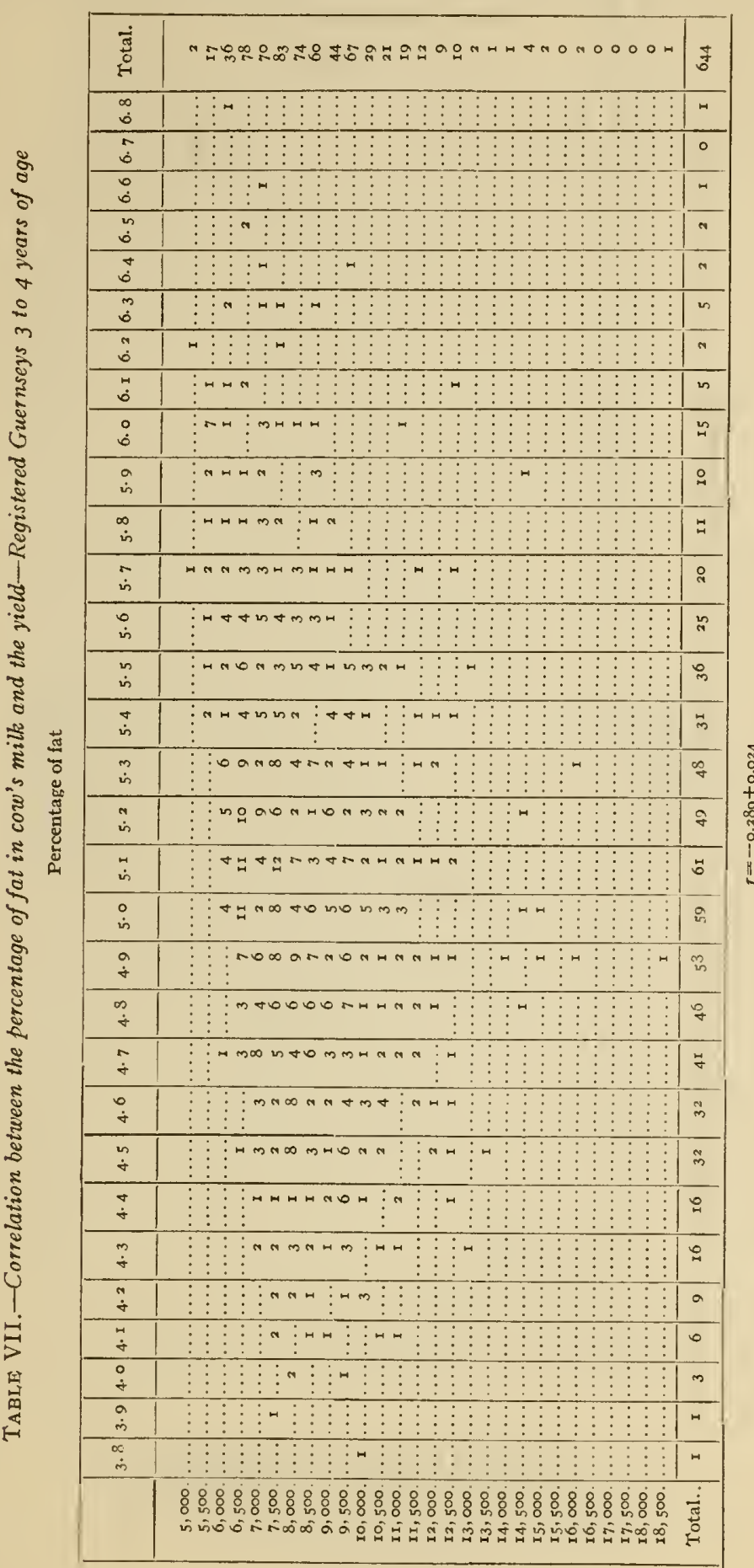




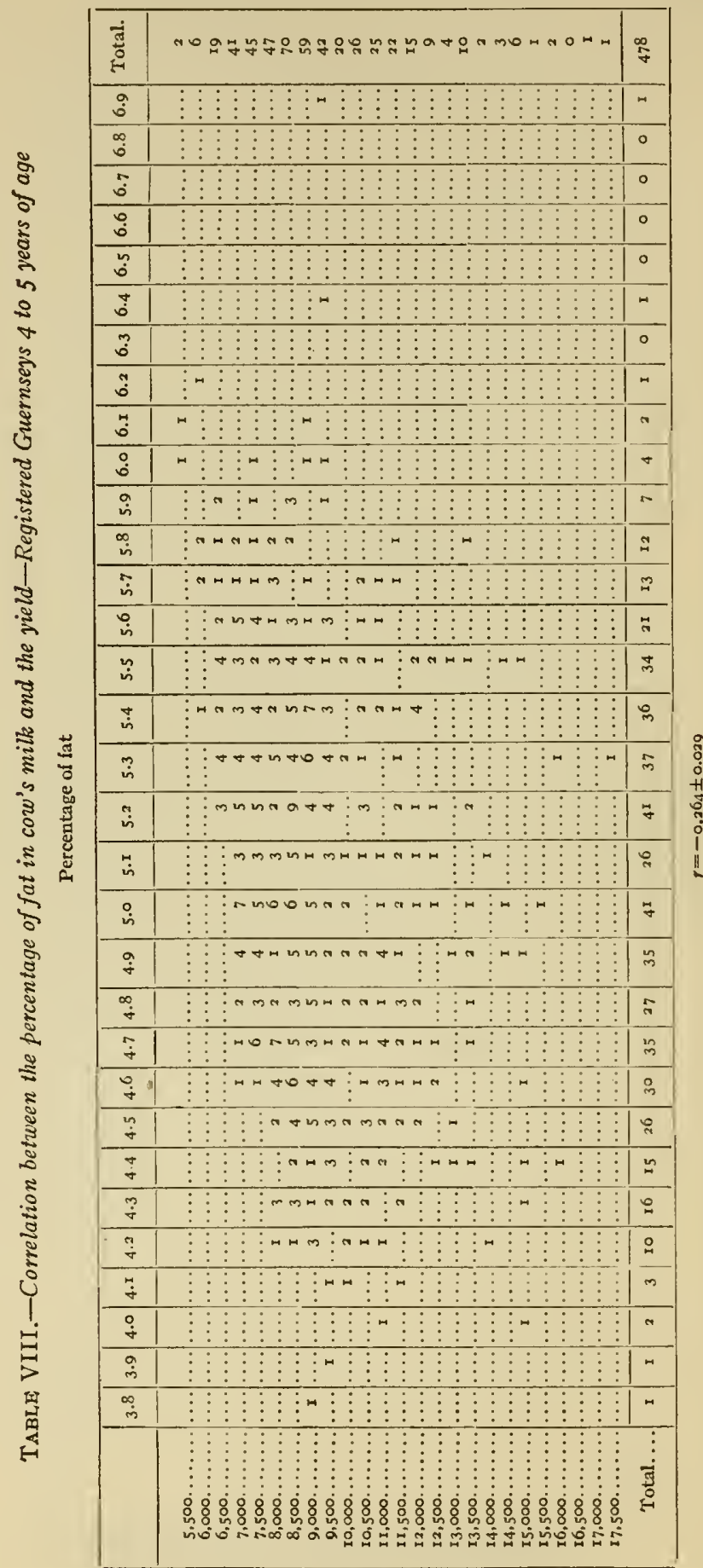

spunod d! 'भा!़ fo plग!x 


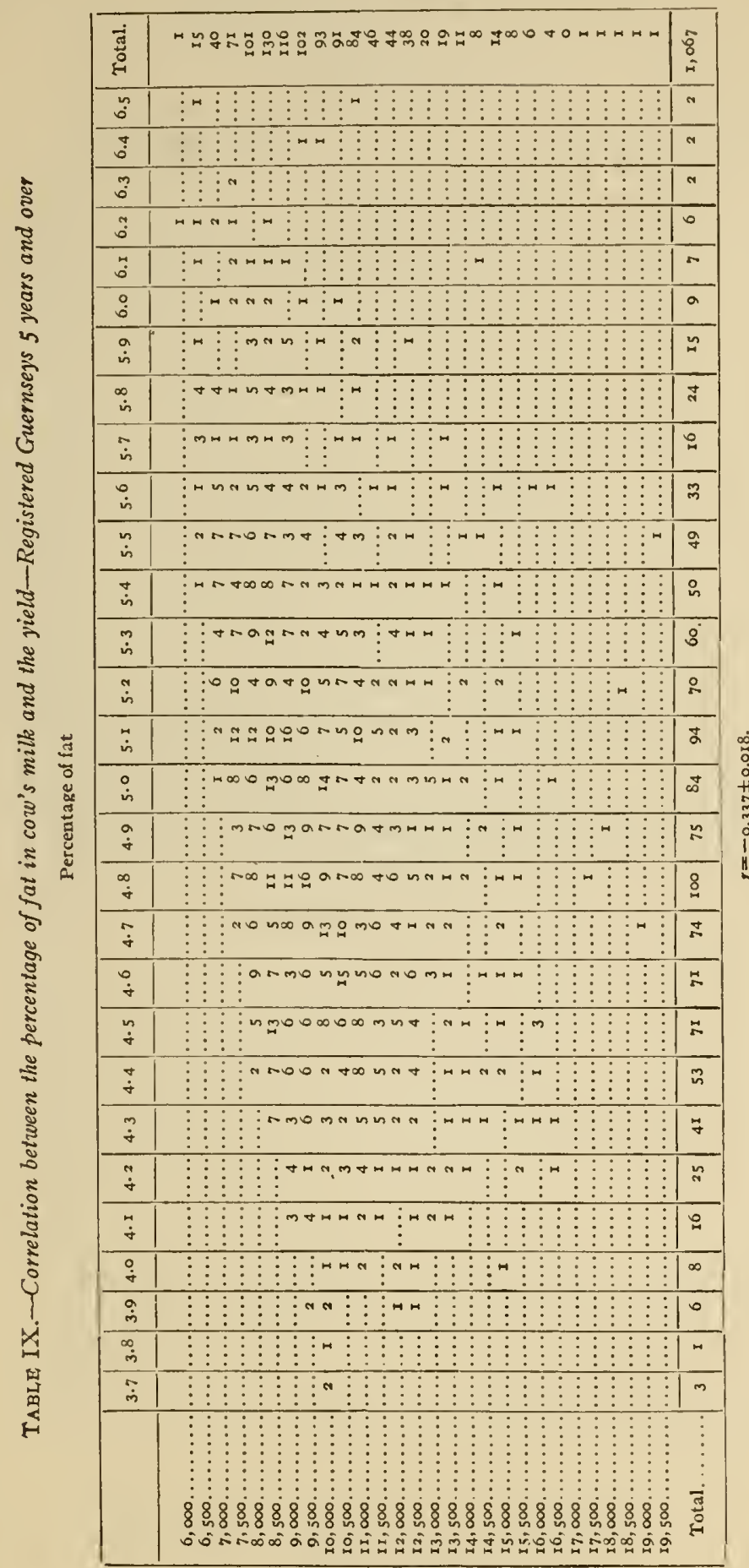




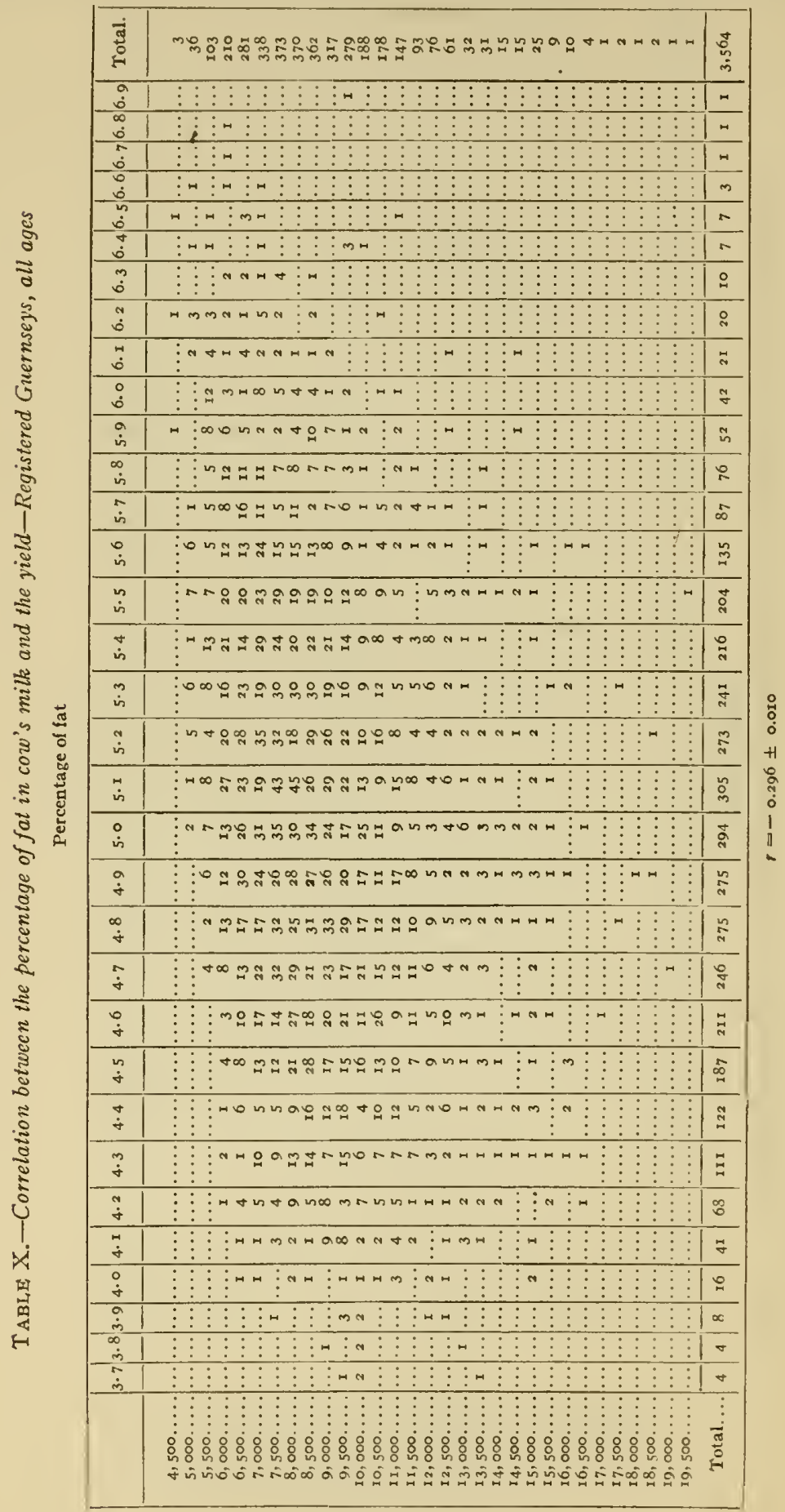


TABLE XI.-Correlation between the percentage of fat in cow's milk and the yield-Registered Holstein-Friesians 2 to 3 years of age

Percentage of fat

\begin{tabular}{|c|c|c|c|c|c|c|c|c|c|c|c|c|c|c|c|c|c|c|c|c|}
\hline & 2.6 & 2.7 & 2.8 & 2.9 & 3.0 & 3.1 & 3.2 & $3 \cdot 3$ & $3 \cdot 4$ & 3.5 & 3.6 & 3.7 & 3.8 & 3.9 & 4.0 & 4. I & $4 \cdot 3$ & 4. 3 & $4 \cdot 4$ & Total. \\
\hline 6,000 . & & & & & & & & & & & & & & & I & & & & & I \\
\hline $6,500 \ldots$ & & .. & & & & & 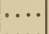 & $\cdots$ & $\cdots$ & & I & & $\cdots$ & $I$ & $\cdots$ & . & .. & - & $\cdots$ & I \\
\hline $\begin{array}{l}7,000 . \\
7,500 .\end{array}$ & & & & & & & & $\because$ & $\cdots$ & $\ddot{2}$ & I & I & 2 & 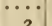 & $\cdots \cdot$ & $\cdots$ & $\cdots$ & & $\cdots$ & 4 \\
\hline 8.000. & & .. & - & & & .... & I & ... & 3 & 2 & $\begin{array}{l}3 \\
4\end{array}$ & I & 2 & 2 & .... & 2 & ... & $\cdots$ & I & 12 \\
\hline $8,500 .$. & & .. & & & 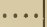 & ... & 4 & 4 & 5 & I & 5 & 2 & 3 & 3 & 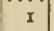 & .... & $\ldots$ & $\ldots$ & $\cdots$ & $\begin{array}{l}23 \\
28\end{array}$ \\
\hline $9,000 \ldots$ & & $\cdots$ & $\cdots$ & I & I & 2 & 2 & 4 & 4 & I & 7 & 7 & 2 & 2 & .. & ... & $\cdots$ & ... & ... & 33 \\
\hline $9.500 .$. & . & $\cdots$ & $\cdots$ & 2 & I & 3 & 1 & 3 & 5 & 3 & 4 & 2 & : & $\mathbf{I}$ & I & I & $\cdots$ & ... & $\cdots$ & 26 \\
\hline $10,000 .$. & & & & .. & 2 & 2 & 6 & 7 & 5 & 6 & 3 & 4 & 2 & & .... & I & $\cdots$ & . & $\cdots$ & 38 \\
\hline I0,500.. & .. & $\cdots$ & $\cdots$ & $\cdots \cdot$ & $\cdots$ & $\cdots$ & 5 & 4 & 3 & 2 & 4 & 4 & 2 & 3 & $\cdots$ & $\cdots \cdot$ & I & ... & $\cdots$ & 28 \\
\hline $\begin{array}{l}11, \infty 00 . \\
\text { II }, 500 .\end{array}$ & $\ldots$ & $\ldots$ & 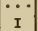 & $\cdots$ & $\begin{array}{l}3 \\
4\end{array}$ & 3 & 3 & $\begin{array}{l}3 \\
6\end{array}$ & $\begin{array}{l}5 \\
5\end{array}$ & $\begin{array}{r}3 \\
\text { II }\end{array}$ & 5 & 4 & $\begin{array}{l}1 \\
2\end{array}$ & $\begin{array}{l}I \\
2\end{array}$ & I & … & ... & $\cdots$ & $\cdots$ & 32 \\
\hline 12,000 . & $\ldots$ & .... & ... & I & I & 2 & 4 & 5 & 8 & 5 & 4 & 4 & I & I & ..... & $I$ & $\ldots$ & . & & $\begin{array}{l}53 \\
37\end{array}$ \\
\hline $12,500 \ldots$ & & 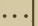 & $\ldots$ & I & .... & 5 & 3 & 5 & 6 & 3 & 5 & 2 & 3 & .. & $\mathrm{I}$ & 2 & I) & ... & $\dddot{I}$ & $\begin{array}{l}57 \\
38\end{array}$ \\
\hline 13,000 . & ... & I & $\cdots$ & 4 & 4 & $x$ & 5 & 5 & 6 & 4 & 4 & 6 & ... & I & .... & $\ldots .$. & $\ldots$ & $\ldots$ & $\ldots$ & $4 \mathrm{I}$ \\
\hline $13,500 \ldots$ & .. & $\cdots$ & $\cdots$ & I & $\cdots$ & 3 & I & & 7 & 6 & 3 & 4 & 2 & I & $\cdots$ & $\cdots \cdots$ & I & I & .. & 30 \\
\hline $14,000 \ldots$ & 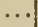 & .. & $\cdots$ & $\cdots \cdot$ & 2 & 2 & 2 & 3 & 3 & 3 & 5 & 4 & 2 & & $\cdots$ & I & I & $\mathrm{r}$ & $\ldots$ & 29 \\
\hline 14,50 & .. & $I$ & $\cdots$ & $\ldots$. & • & 3 & 6 & 3 & & 2 & 4 & I & I & 2 & I & $\ldots$ & $\cdots$ & .. & $\ldots$ & 24 \\
\hline I5,000. & . & ... & ... & I & 3 & 3 & I & 2 & 2 & 7 & 4 & 2 & ... & 2 & .... & $\ldots$ & I & ... & $\ldots$ & 28 \\
\hline I $5,500 \ldots$ & 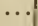 & $\cdots$ & $\mathrm{I}$ & .... & 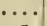 & 2 & 4 & 8 & 7 & 2 & 3 & I & I & I & $\cdots$ & .... & $\cdots$ & ... & ... & 30 \\
\hline $16,000 \ldots$ & .. & $\cdots$ & . & $\cdots$ & I & 2 & 2 & 4 & $\mathrm{I}$ & 2 & I & I & I & I & I & 2 & $\cdots$ & $\ldots$ & ... & 19 \\
\hline 16.500. & .. & ... & $\cdots$ & $\cdots$ & .... & .. & 4 & I & 3 & 4 & 2 & 2 & $\cdots$ & ... & I & $\ldots$ & I & $\ldots$ & $\cdots$ & 18 \\
\hline I 7,000. & $\cdots$ & $\cdots$ & $\cdots$ & I & $\cdots$ & I & & I & I & 2 & 2 & $\cdots$ & I & $\cdots$ & $\cdots$ & $\cdots$ & $\cdots$ & $\cdots$ & $\cdots$ & 9 \\
\hline 27,500 . & $\cdots$ & $\cdots$ & $\dddot{x}$ & $\cdots \cdot$ & $\cdots$ & I & $\mathbf{I}$ & I & & 2 & 3 & $\cdots \cdot$ & $\because$ & $\cdots \cdot$ & $\cdots$ & $\cdots$ & & $\cdots$ & $\cdots$ & \\
\hline $18,000$. & $\cdots$ & $\cdots$ & 1 & $\cdots \cdot$ & I & I & I & $\cdots$ & 2 & $\cdots$ & $I$ & $\cdots \cdot$ & I & $\cdots$ & I & $\cdots \cdots$ & 1 & $\cdots$ & $\cdots$ & I0 \\
\hline $18,500$. & $\cdots$ & $\cdots$ & $\cdots$ & $\cdots$ & I & $\cdots \cdot$ & $\cdots$ & $\cdots \cdot$ & 2 & $\cdots$ & $\cdots$ & I & $\cdots$ & $\cdots \cdot$ & $\cdots \cdot$ & $\cdots \cdot$ & $\cdots$ & $\cdots$ & $\cdots$ & 4 \\
\hline 19.000. & $x^{2}$ & $\cdots$ & $\cdots$ & I & $\cdots \cdot$ & & $\cdots$ & $\cdots \cdot$ & I & I & … & $\cdots$ & $\cdots$ & $\because$ & & & & $\cdots$ & $\cdots$ & 5 \\
\hline 19,500 & $\cdots$ & ‥ & $\cdots$ & $\cdots$ & $\cdots \cdot$ & . & . & .... & $\cdots$ & $\mathbf{I}$ & $\cdots$ & 1 & $\cdots \cdot$ & I & $\cdots$ & $\cdots \cdot \mid$ & $\cdots$ & $\cdots$ & $\cdots$ & 3 \\
\hline 20,000 . & 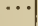 & . & $\cdots$ & .. & $\cdots \cdot$ & .. & . & $\cdots \cdot$ & I & $\cdots$ & I & . & . & $\cdots$ & & $\cdots \cdots$ & $\cdots$ & & $\cdots$ & 2 \\
\hline 20,500 . & & $\cdots$ & & & & $\ldots$ & & & & 1 & & 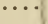 & $\because$ & & & $\cdots$ & $\cdots$ & $\cdots$ & $\cdots$ & I \\
\hline $21,000$. & $\cdots$ & .. & $\cdots$ & . & $\cdots \cdot$ & I & $\ldots$ & . & $\cdots \cdot$ & $\mathbf{I}$ & & . . & I & $\cdots$ & .. & $\cdots \cdot$ & $\cdots$ & ... & $\cdots$ & 3 \\
\hline 21,500 & 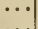 & & - & * & $\cdots \cdot$ & .. & $\cdots$ & … & $\cdots$ & $\cdots$ & $\cdots$ & $\ddot{*}$ & 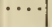 & $\cdots$ & $\ldots$ & $\cdots \cdots$ & $\cdots$ & & $\cdots$ & 0 \\
\hline $\begin{array}{l}2,000 . \\
32,500 .\end{array}$ & & & & & .... & . & & $\ldots$ & & & $\ldots$ & I & & $\cdots$ & . & $\cdots$ & ... & & . & I \\
\hline 23,000 . & ... & 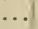 & .. & ... & $\ldots$ & I & .... & .... & $\cdots$ & . & .... & . & ... & $\ldots$ & 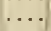 & … & $\ldots$ & . & $\ldots$ & I \\
\hline Total.. & $\mathbf{I}$ & 2 & 3 & I 4 & 24 & 42 & 63 & 68 & 85 & 77 & 83 & 62 & 30 & 25 & 9 & IO & 7 & 2 & 3 & 610 \\
\hline
\end{tabular}


TABLE XII.-Correlation between the percentage of fat in cow's milk and the yield-Registered Holstein-Friesians 3 to 4 years of age

Percentage of fat

\begin{tabular}{|c|c|c|c|c|c|c|c|c|c|c|c|c|c|c|c|c|c|c|c|c|c|}
\hline & 2.6 & $2 \cdot 7$ & 2.8 & 2.9 & 3.0 & $3 \cdot I$ & 3.2 & $3 \cdot 3$ & $3 \cdot 4$ & $3 \cdot 5$ & $3 \cdot 6$ & $3 \cdot 7$ & 3.8 & $3 \cdot 9$ & 4.0 & $4 \cdot x$ & $4 \cdot 2$ & $4 \cdot 3$ & $4 \cdot 4$ & $4 \cdot 5$ & Total. \\
\hline $8, \infty \infty \ldots \ldots$ & & $\cdots$ & ... & & .... & & & ... & $\cdots$ & $\cdots$ & $\cdots$ & I & $I$ & $\cdots$ & $\cdots$ & $\cdots$ & $\cdots$ & $\cdots$ & & & 2 \\
\hline $8,500 \ldots \ldots$ & $\cdots$ & . & $\cdots$ & ... & ... & $\cdots \cdot$ & $\cdots$ & $\cdots \cdot$ & $\cdots$ & I & I & $\ldots$ & I & $\cdots$ & $\ldots$ & $\ldots$ & $\ldots$ & $\ldots$ & $\cdots$ & ... & 3 \\
\hline $9,000 \ldots \ldots$ & $\ldots$ & $\ldots$ & ... & .... & .... & $\ldots$ & 1 & I & I & 2 & 2 & I & 4 & .... & $\ldots$ & $\cdots$ & $\ldots$ & ... & $\cdots$ & ... & I2 \\
\hline $9,500 \ldots .$. & $\ldots$ & 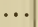 & $\ldots$ & .... & $\ldots$. & $\ldots \ldots$ & $\ldots$ & 2 & $\mathbf{I}$ & I & 2 & I & ... & I & 2 & $\ldots$ & $\ldots$ & $\ldots$ & $\ldots$ & $I$ & I2 \\
\hline $10,000, \ldots .$. & $\cdots$ & $\cdots$ & .. & .... & $\ldots$. & $\cdots$ & $\mathbf{I}$ & $\ldots$ & 2 & 3 & 4 & I & I & $\ldots$ & $\ldots$ & $\ldots$ & $\ldots$ & $\ldots$ & $\cdots$ & $\ldots$ & 12 \\
\hline $10,500 \ldots .$. & $\cdots$ & $\cdots$ & $\cdots$ & $\cdots \cdot$ & $\ldots$. & $\mathbf{r}$ & 2 & $\ldots$ & 2 & $\ldots$. & 6 & 2 & 3 & $\ldots$ & $\cdots$ & $\ldots$ & $\ldots$ & ... & $\ldots$ & $\ldots$ & I6 \\
\hline$I I, \infty 00 \ldots \ldots$ & $\cdots$ & $\cdots$ & I & $\cdots$ & $\cdots \cdot$ & $\mathbf{I}$ & 4 & 3 & $\cdots$ & $\cdots$ & I & I & 3 & 2 & $\ldots$ & $\ldots$ & $\ldots$ & $\cdots$ & $\ldots$ & $\cdots$ & I6 \\
\hline II, $500 \ldots \ldots$ & & $\ldots$ & ... & I & I & 2 & 2 & 2 & 4 & I & I & I & 2 & I & $\ldots$ & $\ldots$ & $\ldots$ & & & $\ldots$ & I8 \\
\hline $12,000 \ldots \ldots$ & $\ldots$ & $\cdots$ & $\mathbf{I}$ & $\mathbf{I}$ & I & 2 & I & 2 & 4 & 2 & $\cdots$ & 2 & I & I & $\cdots$ & $\ldots$ & $\cdots$ & ... & ... & ... & 18 \\
\hline$I_{2}, 500 \ldots \ldots$ & $\cdots$ & $\cdots$ & $\cdots$ & $\ldots$ & I & $\ldots$. & I & 4 & 4 & I & 2 & 2 & $\ldots$. & $\ldots$ & I & $\ldots$ & $\ldots$ & I & $\mathbf{I}$ & ... & 18 \\
\hline $13,000 \ldots \ldots$ & $\cdots$ & $\ldots$ & I & $\mathbf{r}$ & I & 2 & I & I & 5 & 2 & I & 2 & I & I & ... & I & $\ldots$ & ... & ... & ... & 20 \\
\hline$I_{3}, 500 \ldots \ldots$ & I & $\cdots$ & $\cdots$ & 2 & I & 4 & 5 & 3 & 3 & 3 & 7 & 2 & 3 & I & I & $\cdots$ & $\ldots$ & $\ldots$ & $\ldots$ & $\ldots$ & 36 \\
\hline $14,000, \ldots$. & $\cdots$ & $\mathbf{I}$ & I & I & $\ldots$ & 2 & 3 & 2 & 2 & 2 & $\ldots$ & $\mathbf{I}$ & 2 & $\ldots$ & $\ldots$ & $\ldots$ & $\mathbf{I}$ & $\ldots$ & $\ldots$ & ... & 18 \\
\hline$I 4,500, \ldots \ldots$ & $I$ & $\ldots$ & $\cdots$ & $\ldots$ & 2 & $\ldots$. & 2 & 5 & 2 & 4 & 2 & $\mathbf{I}$ & I & 2 & $\ldots$ & $\ldots$ & $\ldots$ & $\cdots$ & $\ldots$ & $\ldots$ & 22 \\
\hline $1_{5}, \infty 00 \ldots$. & $\ldots$ & $\ldots$ & I & $\ldots$ & $\ldots$ & 3 & $\ldots$. & 2 & 3 & 2 & 2 & $\ldots$ & I & $\ldots$ & $\ldots$ & $\ldots$ & $\ldots$ & $\ldots$ & $\ldots$ & ... & $I_{4}$ \\
\hline I5, $500 \ldots \ldots$ & $\ldots$ & $\cdots$ & $\ldots$ & $\ldots$ & 2 & I & $\ldots$ & $\mathbf{I}$ & 3 & $\ldots$ & 3 & $\ldots$ & $\ldots$ & I & 2 & 2 & $\ldots$ & $\ldots$ & $\ldots$ & $\ldots$ & I5 \\
\hline$I 6, \infty 00 \ldots \ldots$ & $\cdots$ & $\cdots$ & $\ldots$ & $\mathbf{I}$ & 2 & 2 & 3 & $\ldots$ & 3 & 21 & I & $\cdots$ & $\cdots$ & $\ldots$ & ... & $\cdots$ & $\mathbf{I}$ & $\ldots$ & $\ldots$ & $\ldots$ & I5 \\
\hline$I 6,500 \ldots \ldots$ & $\ldots$ & $\cdots$ & $\ldots$ & $\ldots$ & ... & 2 & $\ldots$ & 5 & I & $\ldots$ & 2 & 2 & $\ldots$. & $\ldots$ & ... & $\ldots$ & $\ldots$ & $\ldots$ & $\ldots$ & $\ldots$ & I2 \\
\hline I7, $000 \ldots \ldots$ & $\cdots$ & $\ldots$ & $\ldots$ & $\ldots$ & $\ldots$ & 2 & I & $\ldots$ & $\ldots$ & 2 & $\ldots$ & $\ldots$ & I & $\ldots$ & $\ldots$ & $\ldots$ & $\ldots$ & $\ldots$ & $\ldots$ & $\ldots$ & 6 \\
\hline$I 7,500 \ldots \ldots$ & $\cdots$ & $\ldots$ & $\ldots$ & I & 2 & 21 & $\ldots$ & I & 5 & $\ldots$ & I & $\ldots$ & $\mathbf{I}$ & I & $\ldots$ & I & $\ldots$ & 1... & ... & $\ldots$ & I5 \\
\hline$I 8,000 \ldots \ldots$ & $\cdots$ & $\cdots$ & $\ldots$ & $\ldots$ & $\ldots$ & $\ldots$ & $\ldots$ & 2 & $\mathbf{I}$ & I & I & .... & $\ldots$ & $\ldots$ & $\cdots$ & $\ldots$ & ... & $\ldots$ & ... & $\cdots$ & 5 \\
\hline$I 8,500 \ldots \ldots$ & $\cdots$ & $\cdots$ & $\cdots$ & I & I & $\cdots$ & 2 & I & 2 & $\cdots$ & $\cdots$ & $\ldots$ & I & $\cdots$ & $\cdots$ & $\cdots$ & ... & $\cdots$ & $\cdots$ & $\cdots$ & 8 \\
\hline $19,000 \ldots \ldots$ & $\cdots$ & $\cdots$ & $\cdots$ & $\mathbf{I}$ & $\ldots$ & ... & $\cdots \cdot$ & $\mathbf{I}$ & 2 & 2 & I & .... & $\cdots \cdot$ & $\cdots$ & $\cdots$ & $\ldots$ & $\cdots$ & I & $\cdots$ & $\cdots$ & 8 \\
\hline $19,500, \ldots \ldots$ & $\cdots$ & $\cdots$ & $\cdots$ & $\cdots$ & $\cdots$ & $\cdots$ & $\cdots$ & I & $\mathbf{I}$ & 2 & $\cdots$ & $\cdots$ & $\cdots$ & $\cdots$ & $\cdots$ & $\cdots$ & $\cdots$ & $\cdots$ & $\cdots$ & $\cdots$ & 4 \\
\hline $20,000 \ldots \ldots$ & $\cdots$ & $\cdots$ & I & $\cdots$ & I & $\cdots \cdot$ & $\cdots \cdots$ & 2 & $\cdots \cdot$ & $\cdots$ & $\cdots \cdots$ & $\cdots \cdots$ & $\cdots$ & $\cdots$ & $\cdots$ & $\cdots$ & $\cdots$ & $\cdots$ & $\cdots$ & $\cdots$ & 4 \\
\hline $\begin{array}{l}20,500 \ldots \ldots \\
21,000 \ldots\end{array}$ & $\cdots$ & $\cdots$ & $\cdots$ & 1 & $\cdots$ & $\cdots$ & $\cdots$ & $\cdots$ & $\cdots$ & $\cdots \cdot \mid$ & $\cdots$ & $\cdots \cdot \mid$ & $\cdots \cdot$ & $\cdots$ & $\cdots$ & $\cdots$ & $\cdots$ & $\cdots$ & $\cdots$ & $\cdots$ & I \\
\hline $\begin{array}{l}21,000 \ldots \ldots \\
21,500 \ldots \ldots\end{array}$ & $\cdots$ & $\cdots$ & {$\left[\begin{array}{l}\cdots \\
\cdots\end{array} \mid\right.$} & $|\cdots \cdot|$ & $\cdots$ & $\ddot{m}_{\mathrm{I}}$ & $\cdots$ & $\cdots$ & $\begin{array}{c}\mathbf{I} \\
\ldots . .\end{array}$ & {$\left[\begin{array}{c}\cdots \\
I\end{array}\right]$} & I & $|\cdots|$ & $\cdots$ & $\cdots$ & $\cdots$ & $\cdots$ & $\because$ & $\cdots$ & $\cdots$ & $\cdots$ & 2 \\
\hline $22,000 \ldots \ldots$ & $\ldots$ & $\ldots$ & $\cdots$ & $\ldots$ & $\ldots$ & $\ldots$ & 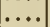 & $\cdots$ & $\cdots \cdots$ & $\ldots$ & $\cdots$ & $\left|\begin{array}{l}\cdots \\
\cdots \cdots\end{array}\right|$ & $|\cdots \cdot|$ & $\cdots$ & $\cdots$ & $\cdots$ & $\ldots$ & $\because$ & $\cdots$ & $\cdots$ & $\begin{array}{l}2 \\
0\end{array}$ \\
\hline $22,500 \ldots \ldots$ & $\ldots$ & I & $\ldots$ & $\ldots$ & $\ldots$ & $\ldots$ & $\ldots$ & I & $\ldots$ & $\ldots$ & $\ldots$ & $\ldots$ & $\ldots$ & $I$ & $\cdots$ & $\cdots$ & $\cdots$ & $\ldots$ & $\cdots$ & $\cdots$ & $\begin{array}{l}0 \\
3\end{array}$ \\
\hline $23,000 \ldots \ldots$ & $\ldots$ & $\ldots$ & $\ldots$ & $\ldots$ & $\ldots$ & $\ldots$ & I & $\ldots$ & .... & $\ldots$ & $\ldots$ & $\ldots$ & $\ldots$ & $\ldots$ & I & $\cdots$ & $\because$ & $\ldots$ & $\ldots$ & & $\begin{array}{l}3 \\
2\end{array}$ \\
\hline $23,500, \ldots \ldots$ & $\ldots$ & $\ldots$ & $\ldots$ & $\cdots$ & $\ldots$ & $\ldots$ & $\ldots$ & $1 \ldots$. & & & $\ldots$ & $\ldots$ & $\ldots$. & & $\ldots$ & $\cdots$ & $\cdots$ & $\ldots$ & $\ldots$ & $\cdots$ & $\begin{array}{l}2 \\
0\end{array}$ \\
\hline $24, \infty 00, \ldots$. & $\cdots$ & . & $\cdots$ & $\ldots$ & I & .... & & .... & . & $\cdots$ & .. & $\ldots$ & .. & . & . & .. & $\ldots$ & .. & $\ldots$ & $\ldots$ & $\begin{array}{l}0 \\
\text { I }\end{array}$ \\
\hline $24,500 \ldots \ldots$ & $\cdots$ & $\cdots$ & $\cdots$ & $\ldots$ & $\ldots$. & $\cdots$ & $\ldots$ & $\ldots$ & $\cdots$ & $\ldots$ & $\ldots$ & $\ldots$. & $\ldots$ & $\ldots$ & $\ldots$ & $\ldots$ & $\cdots$ & $\ldots$ & . & $\mathbf{I}$ & I \\
\hline Total ... & 2 & 2 & 6 & II & 16 & 27 & 30 & $4^{2}$ & 52 & 34 & 42 & 20 & 27 & 12 & 7 & 4 & 2 & 2 & I & 2 & $34 I$ \\
\hline
\end{tabular}


July 8,1918

Percentage of Fat in Cow's Milk

89

TABLE XIII.-Correlation between the percentage of fat in cow's milk and the yieldRegistered Holstein-Friesians 4 to 5 years of age

Percentage of fat

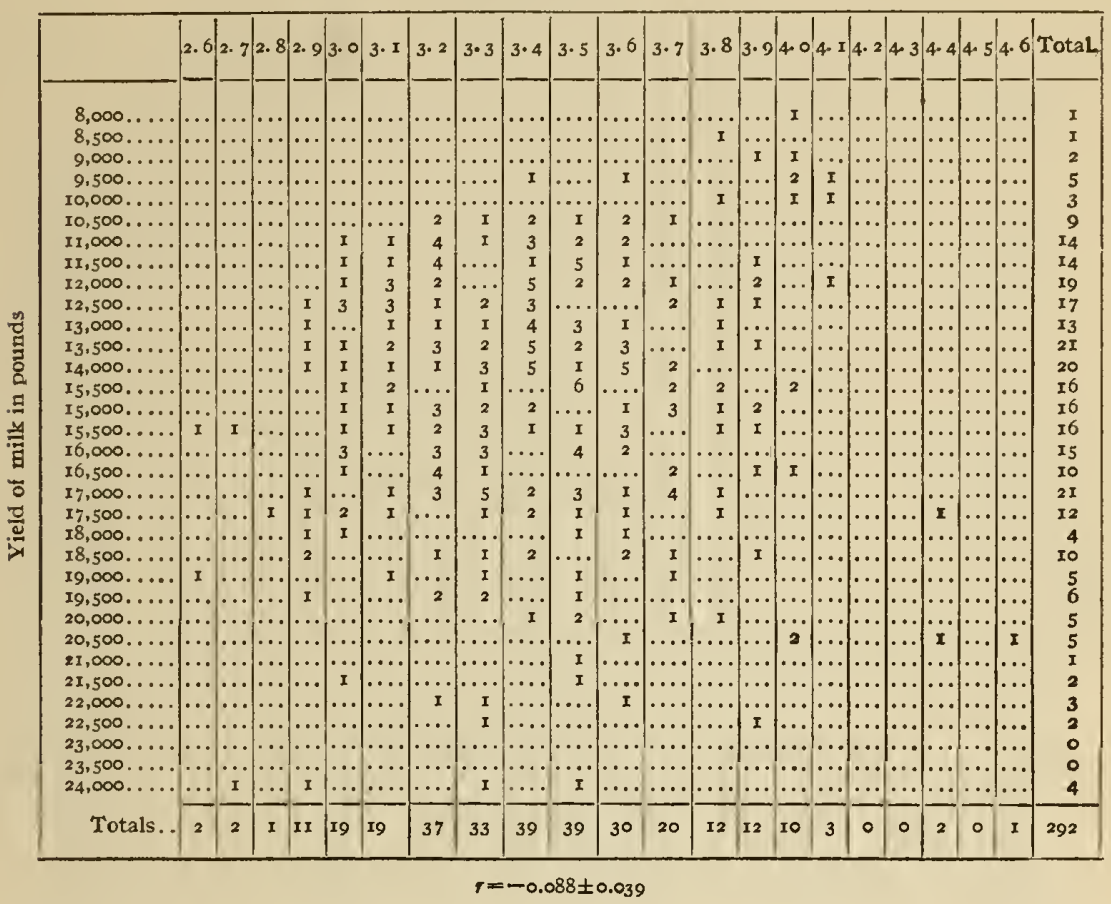


TABIE XIV.-Correlation between the percentage of fat in cow's milk and the yieldRegistered Holstein-Friesians 5 years and over

Percentage of fat

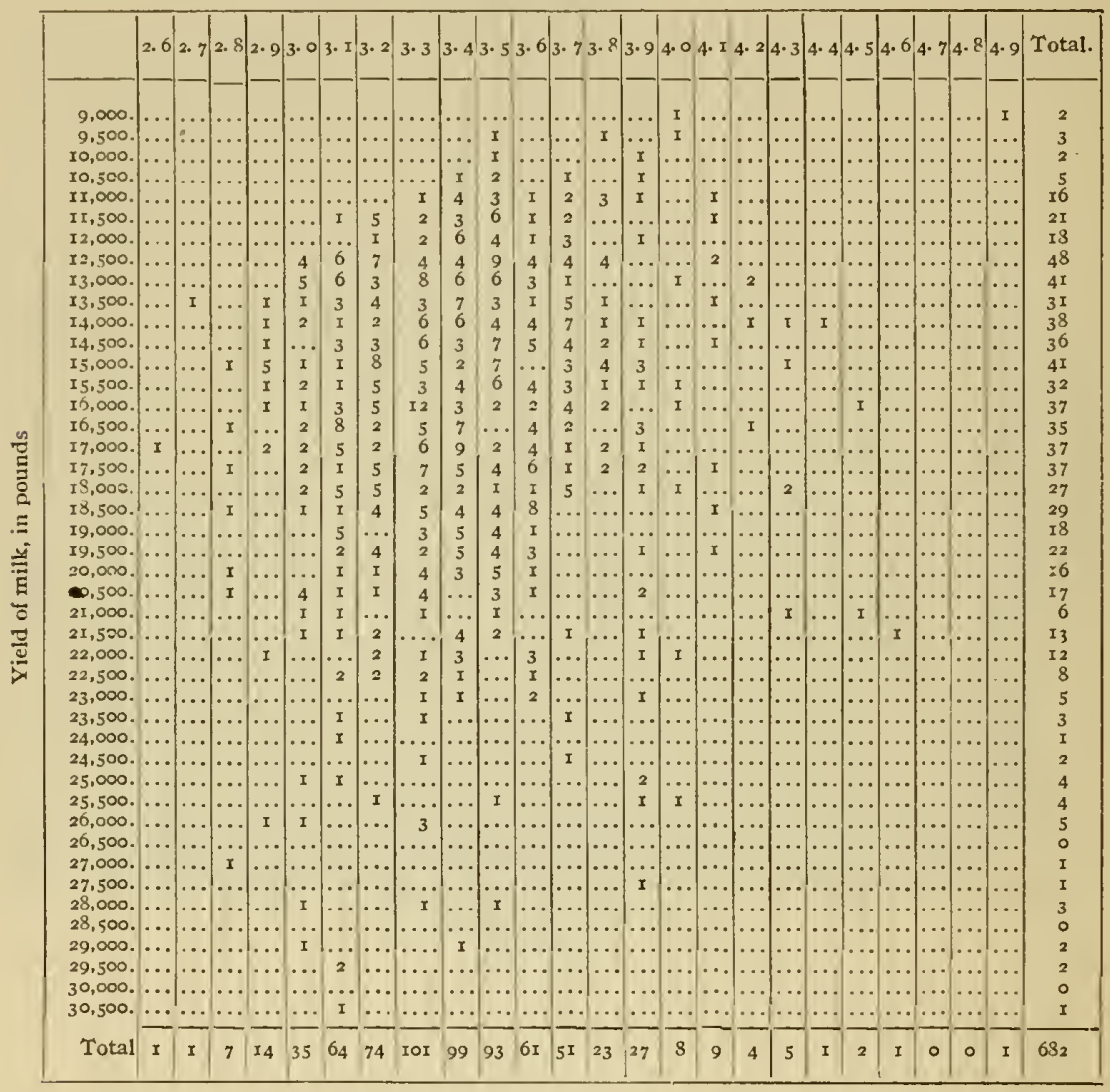

$r=-0.115 \pm 0.026$ 
TABLE XV.-Correlation between the percentage of fat in cow's milk and the yieldRegistered Holstein-Friesians, all ages

Percentage of fat

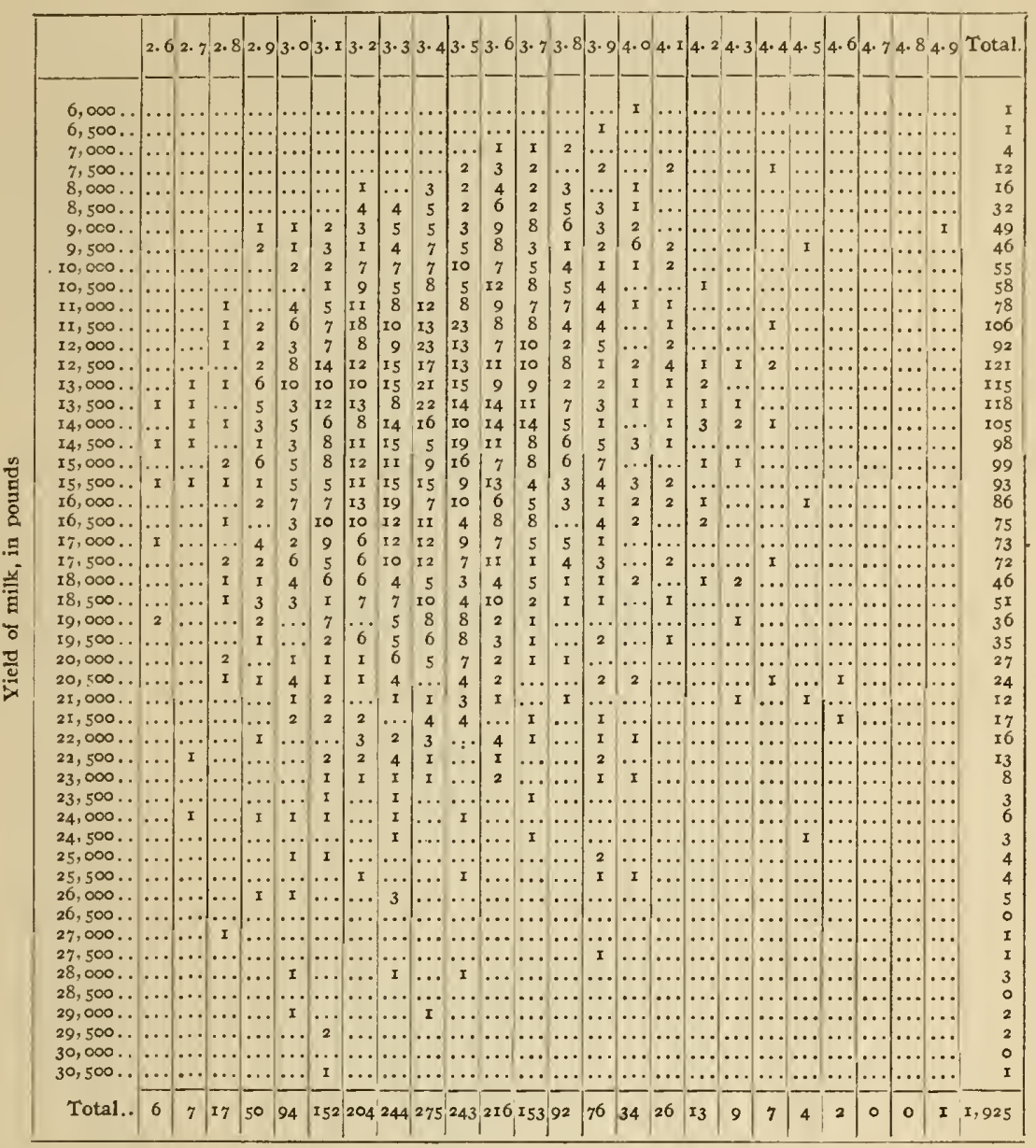




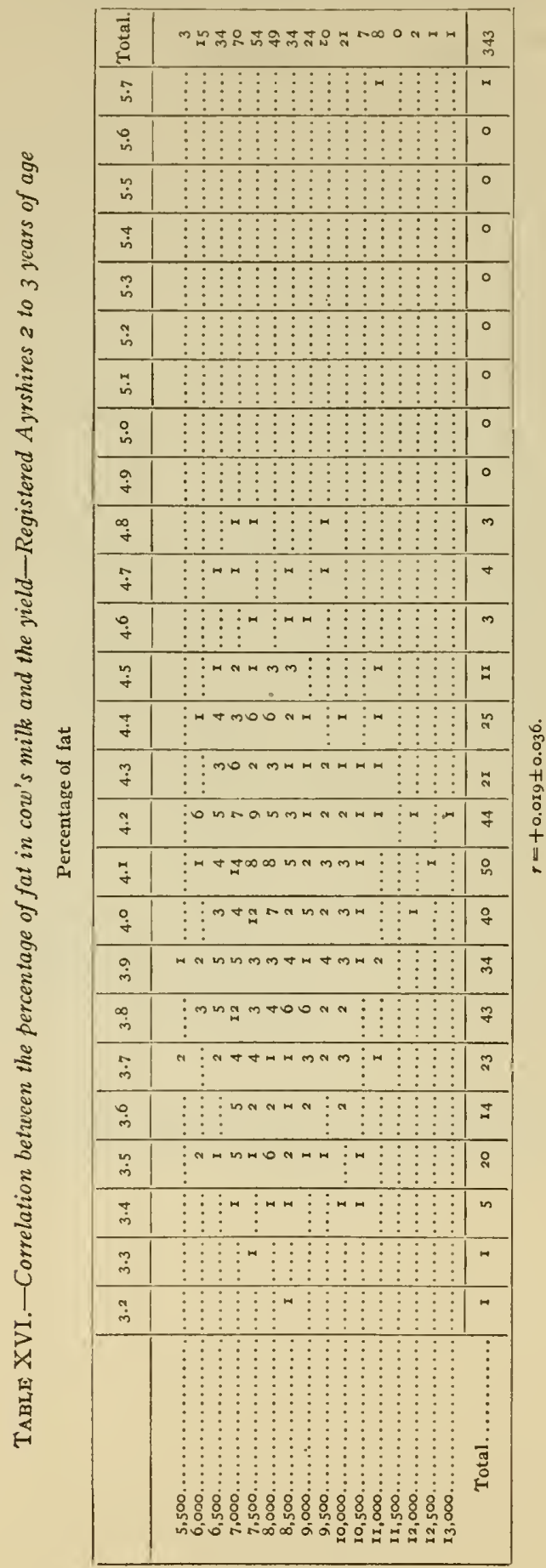

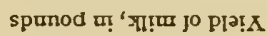


TABLE XVII.-Correlation between the percentage of fat in cow's milk and the yield-Registered Ayrshires 3 to 4 years of age

Percentage of fat

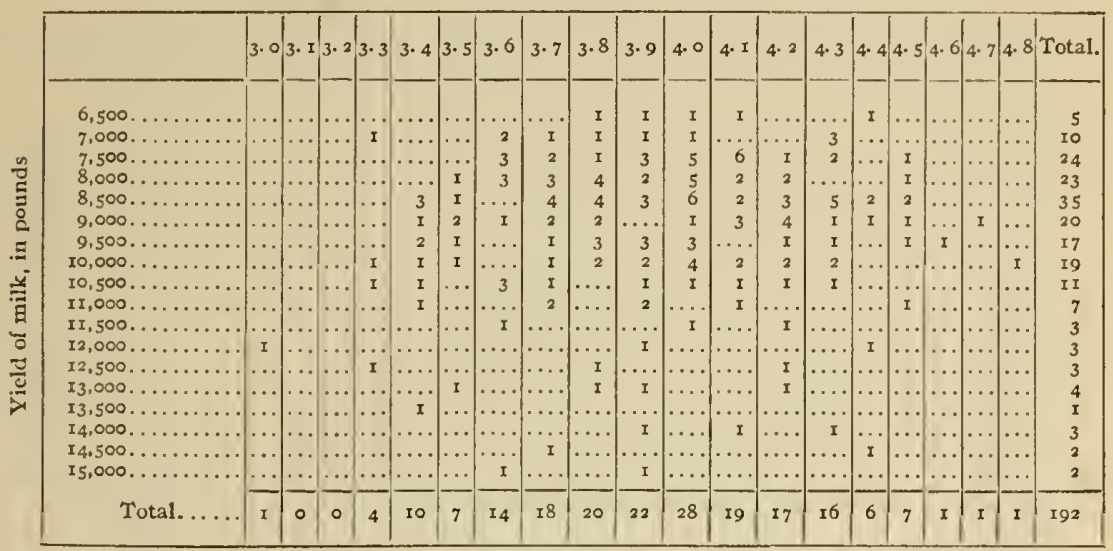

$y=-0.093 \pm 0.048$

TABLE XVIII.-Correlation between the percentage of fat in cow's milk and the yieldRegistered Ayrshires 4 to 5 years of age

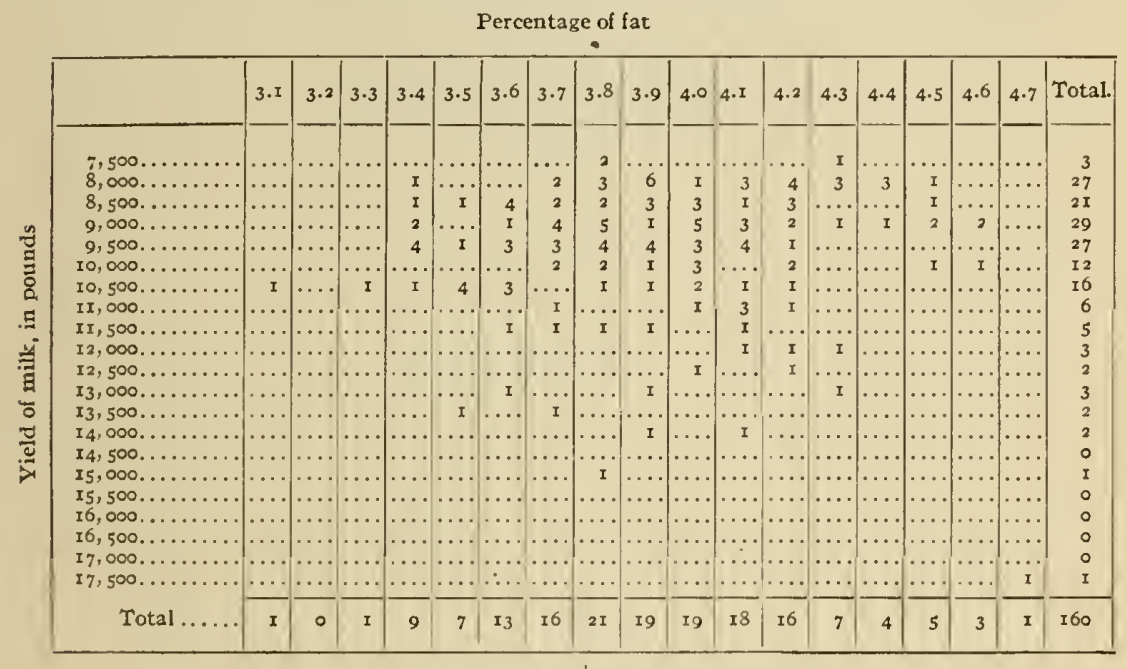

$r=-0.023 \pm 0.053$ 
94

Journal of Agricultural Research

Vol. XIV, No. 2

TABLE XIX. -Correlation between the percentage of fat in cow's milk and the yieldRegistered Ayrshires 5 years and over.

Percentage of fat

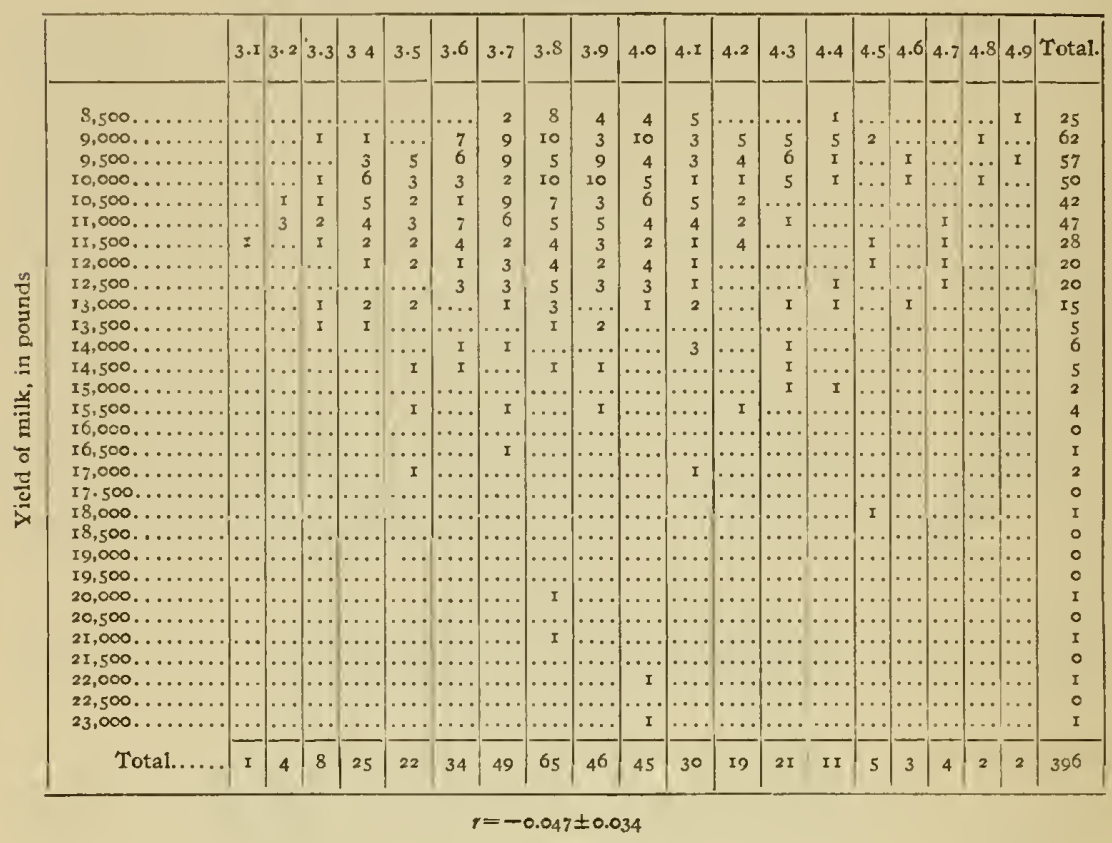




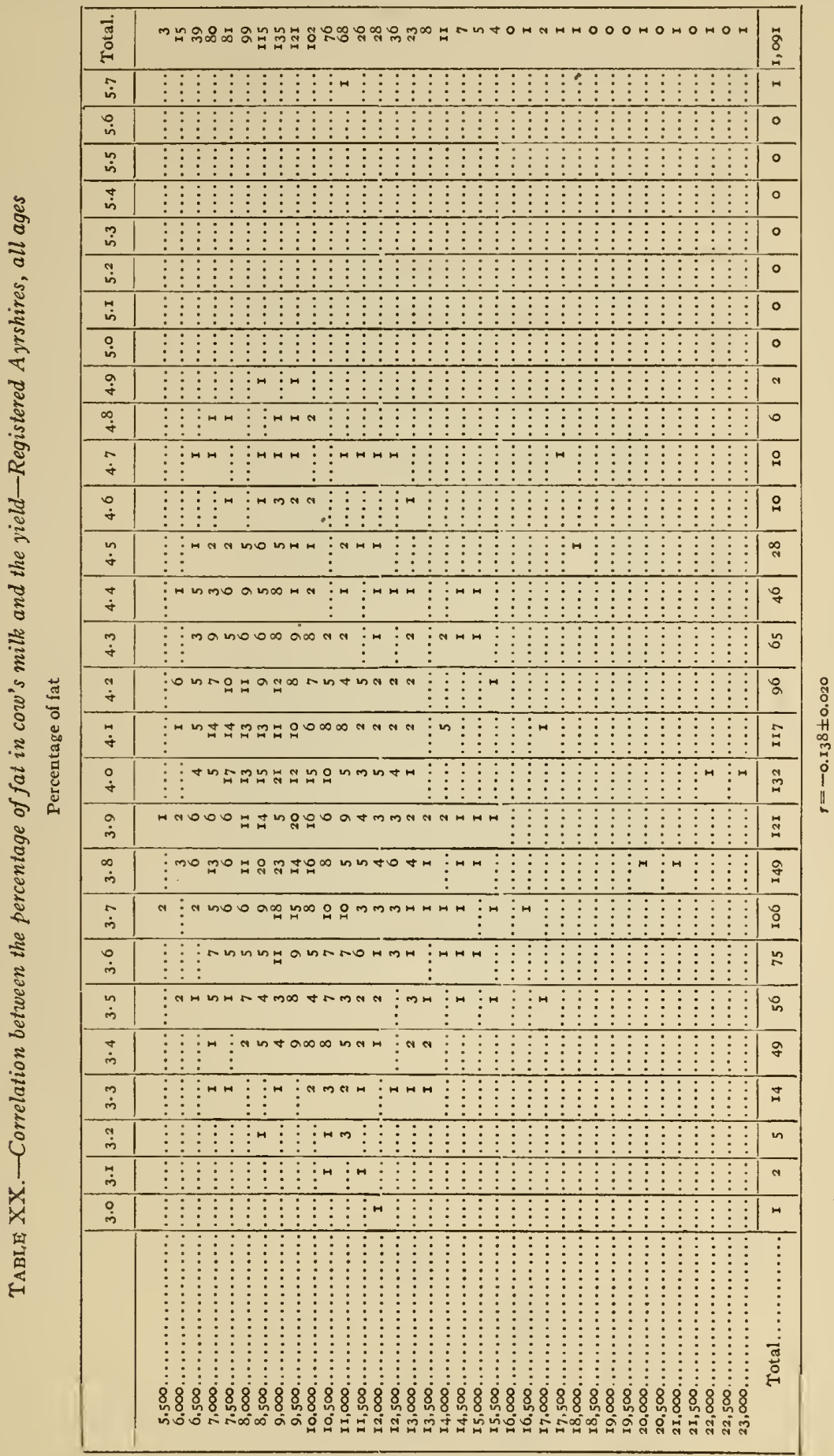




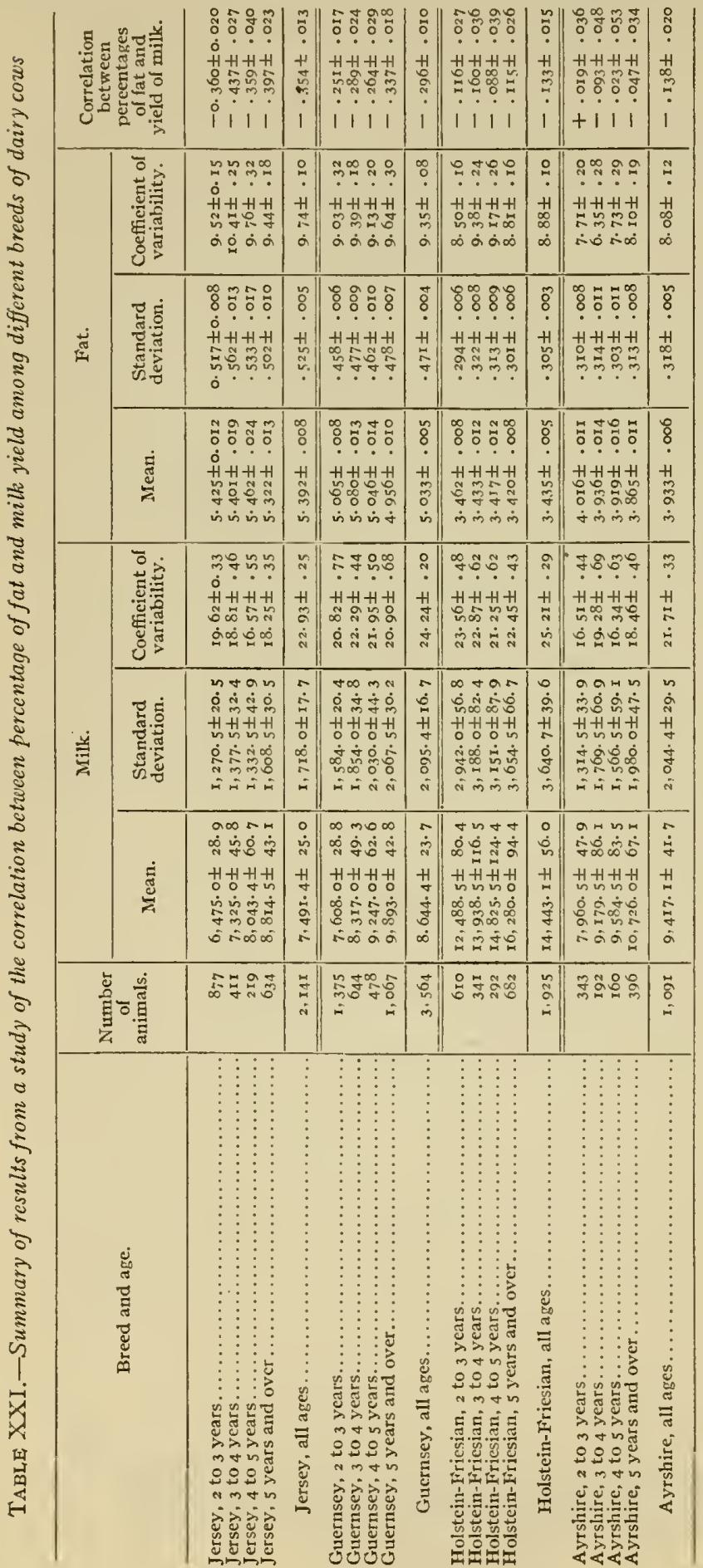





Pamphlet

Gaylord Bros.

Makers
Syracuse, N. Y.
PAI. JAN 21, 1908

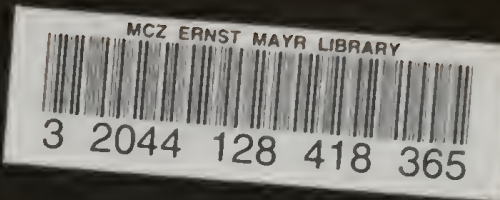


